Zimmer, Riggs, and Carrasco-Nunez, 2010, Evolution of tuff ring-dome complex: the case study of Cerro Pinto, eastern Trans-Mexican Volcanic Belt, Bulletin of Volcanology, DOI 10.1007/s00445-010-0391-6 Published by Springer Verlag. The original publication is available at www.springerlink.com (ISSN: 0258-8900) June 29, 2010.

Keywords Rhyolite | Dome Complex | Tuff Ring | Phreatomagmatism | Trans-Mexican Volcanic Belt

\title{
Evolution of tuff ring-dome complex: the case study of Cerro Pinto, eastern Trans-Mexican Volcanic Belt
}

\author{
Brian W. Zimmer, Nancy R. Riggs and Gerardo Carrasco-Núñez
}

\begin{abstract}
Cerro Pinto is a Pleistocene rhyolite tuff ring-dome complex located in the eastern Trans-Mexican Volcanic Belt. The complex is composed of four tuff rings and four domes that were emplaced in three eruptive stages marked by changes in vent location and eruptive character. During Stage I, vent clearing produced a 1.5-km-diameter tuff ring that was then followed by emplacement of two domes of approximately $0.2 \mathrm{~km}^{3}$ each. With no apparent hiatus in activity, Stage II began with the explosive formation of a tuff ring $\sim 2 \mathrm{~km}$ in diameter adjacent to and north of the earlier ring. Subsequent Stage II eruptions produced two smaller tuff rings within the northern tuff ring as well as a small dome that was mostly destroyed by explosions during its growth. Stage III involved the emplacement of a $0.04 \mathrm{~km}^{3}$ dome within the southern tuff ring. Cerro Pinto's eruptive history includes sequences that follow simple rhyolite-dome models, in which a pyroclastic phase is followed immediately by effusive dome emplacement. Some aspects of the eruption, however, such as the explosive reactivation of the system and explosive dome destruction, are more complex. These events are commonly associated with polygenetic structures, such as stratovolcanoes or calderas, in which multiple pulses of magma initiate reactivation. A comparison of major and trace element geochemistry with nearby Pleistocene silicic centers does not show indication of any co-genetic relationship, suggesting that Cerro Pinto was produced by a small, isolated magma chamber. The compositional variation of the erupted material at Cerro
\end{abstract}


Pinto is minimal, suggesting that there were not multiple pulses of magma responsible for the complex behavior of the volcano and that the volcanic system was formed in a short time period. The variety of eruptive style observed at Cerro Pinto reflects the influence of quickly exhaustible water sources on a short-lived eruption. The rising magma encountered small amounts of groundwater that initiated eruption phases. Once a critical magma:water ratio was exceeded, the eruptions became dry and sub-plinian to plinian. The primary characteristic of Cerro Pinto is the predominance of fall deposits, suggesting that the level at which rising magma encountered water was deep enough to allow substantial fragmentation after the water source was exhausted. Isolated rhyolite domes are rare and are not currently viewed as prominent volcanic hazards, but the evolution of Cerro Pinto demonstrates that individual domes may have complex cycles, and such complexity must be taken into account when making hazard risk assessments.

\section{ARTICLE}

\section{Introduction}

Rhyolite domes are commonly considered simple, monogenetic structures with only localized hazard implications. The majority of reports of rhyolite domes propose emplacement through a single, predictable evolutionary path that includes an initial pyroclastic phase followed by the effusive emplacement of dome lava (Swanson et al. 1989; Duffield et al. 1995). Recent work, however, documents a more complex evolution of isolated rhyolite domes, involving reactivation, vent migration, sector collapse, and significant changes in eruptive style (Riggs and Carrasco-Núñez 2004; Carrasco-Núñez and Riggs 2008). This divergence from traditional views concerning rhyolite dome growth has direct implications in the analysis of existent dome systems as well as for hazard assessments related to eruptions that produce new rhyolite domes.

Tuff rings and tuff cones of dacitic to rhyolitic composition are recognized throughout the world (Sheridan and Updike 1975; Heiken and Wohletz 1987; Brooker et al. 1993; Austin-Erickson 2007; Carrasco-Núñez et al. 2007) though first-hand scientific observation of this type of eruption is notably rare. This paper describes Cerro Pinto, a Pleistocene, rhyolite, tuff ring-dome complex that has the volume and chemical signature characteristic of simple, monogenetic, rhyolite domes, but conflictingly, has variations in eruptive styles, such as vent migration, explosive reactivation, and dome collapse that are more commonly associated with polygenetic volcanism. Rhyolite domes associated with larger volcanic structures such as calderas and stratovolcanoes are common (i.e. Novarupta, Valley of Ten Thousand Smokes, Alaska; Hildreth and 
Fierstein 2000; Houghton et al. 2004; Shtyubel volcano, Russia; Macias and Sheridan 1995; Puketarata, New Zealand; Brooker et al. 1993; Inyo Domes, Long Valley caldera, California, Miller 1985; Sampson and Cameron 1987; Hildreth 2004) and often are complex in chemical evolution. Multi-phase eruptions from a single, isolated batch of magma, however, are not well documented, nor are they well understood. This study has two goals: 1) to provide the first detailed description of Cerro Pinto, its deposits, and the sequence of eruptive events that formed the volcano complex, and 2) to identify the main controlling factors that made Cerro Pinto's eruption different from many other rhyolite dome eruptions.

\section{Geologic setting}

Cerro Pinto tuff ring-dome complex is located approximately $150 \mathrm{~km}$ east of Mexico City in the state of Puebla (Fig. 1). Rhyolitic volcanoes within the Serdán-Orientál basin include Los Humeros caldera (Ferriz and Mahood 1984), Tepexitl maar (Austin-Erickson 2007; Austin-Erickson et al. 2008), and the isolated domes Cerro Pinto, Cerro Pizarro (Riggs and Carrasco-Núñez 2004; Carrasco-Núñez and Riggs 2008), Las Derrumbadas (Siebe et al. 1995), and Las Aguilas. The regional basement is predominately Cretaceous limestone that was folded during the Laramide Orogeny and intruded by small plutons of granodiorite, monzonite, and syenite during Oligocene and Miocene times (Yañez and García 1982). Nearby maar and tuff cone volcanoes provide insight into the character of the aquifers of the Serdán-Oriental basin. Less than $5 \mathrm{~km} \mathrm{SW}$ of Cerro Pinto is Atexcac maar, where the aquifer is composed of fractured andesite and limestone (Carrasco-Núñez et al. 2007). Farther south, at Tecuitlapa maar, the underlying aquifer is composed of granular tuff deposits (Toba Café) that were likely involved in the phreatomagmatic eruptions that formed that maar (Ort and CarrascoNúñez 2009). Cerro Xalapaxco tuff cone was formed by phreatomagmatic eruptions initiated by contact between a rising magma body and an aquifer of limestone and glacio-fluviatile deposits (Abrams and Siebe 1994). The basement beneath Cerro Pinto also includes Tertiary volcanic deposits of andesite, basaltic andesite, and basalt (Ferriz and Mahood 1984). Surface water is generally scarce due to the prevalence of highly permeable volcanic rock deposits. However, the basin is home to two large saltpans and the aforementioned maar volcanoes, indicating that the water table has often been close to the surface. 


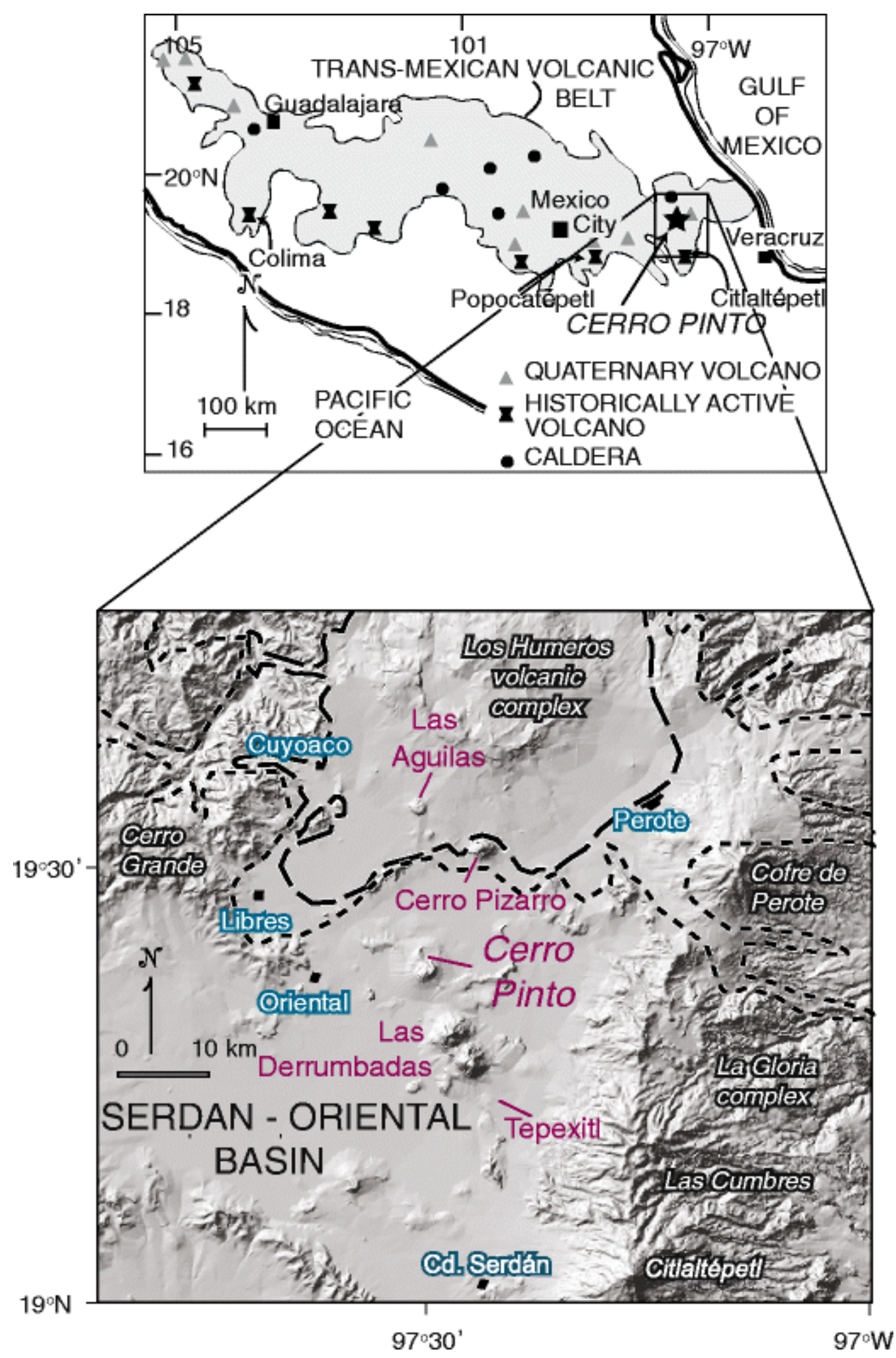

Fig. 1 Location of Cerro Pinto and the Trans-Mexican Volcanic Belt in Mexico (after Siebert and CarrascoNuñez 2002; Riggs and Carrasco-Núñez 2004). Large volcanoes and complexes on the rim of the Serdán-Orientál basin in italicized text; rhyolitic centers in the basin in bold 


\section{Terminology}

Certain terms in this paper have been used in different ways in literature and are defined here to avoid confusion. An "isolated dome" is a lava dome whose evolution was not associated with any other prominent volcanic features (e.g. stratovolcano, caldera, or larger dome field). The term "tuff ring" is commonly used for any circular or quasi-circular set of pyroclastic deposits emplaced from a single, central vent during phreatomagmatic eruptions. At Cerro Pinto the definition is expanded to include rings of tephra without any apparent phreatomagmatic influence. Proximal deposits are those deposits located within the rim of the tuff ring produced by a particular eruptive stage and distal deposits are those deposits emplaced beyond the rim. In most cases at Cerro Pinto, proximal deposits are within $1 \mathrm{~km}$ of their source vents. The term "outsized clast" refers to any clast more than five times the average grain size for any deposit. Outsized clasts can include blocks or bombs, but the term does not imply any particular process.

\section{Lithofacies of Cerro Pinto}

The volcano is high-silica rhyolite with minor phenocryst populations of biotite, plagioclase, quartz, and sanidine (1-5\% total volume). The complex is distinctly shaped like the number 8 , with two large adjacent tuff rings aligned north-south. The southern tuff ring encircles the three largest domes that rise up to $750 \mathrm{~m}$ above the valley floor while the northern tuff ring encircles a smaller dome and two partially eroded tuff rings (Fig. 2). 


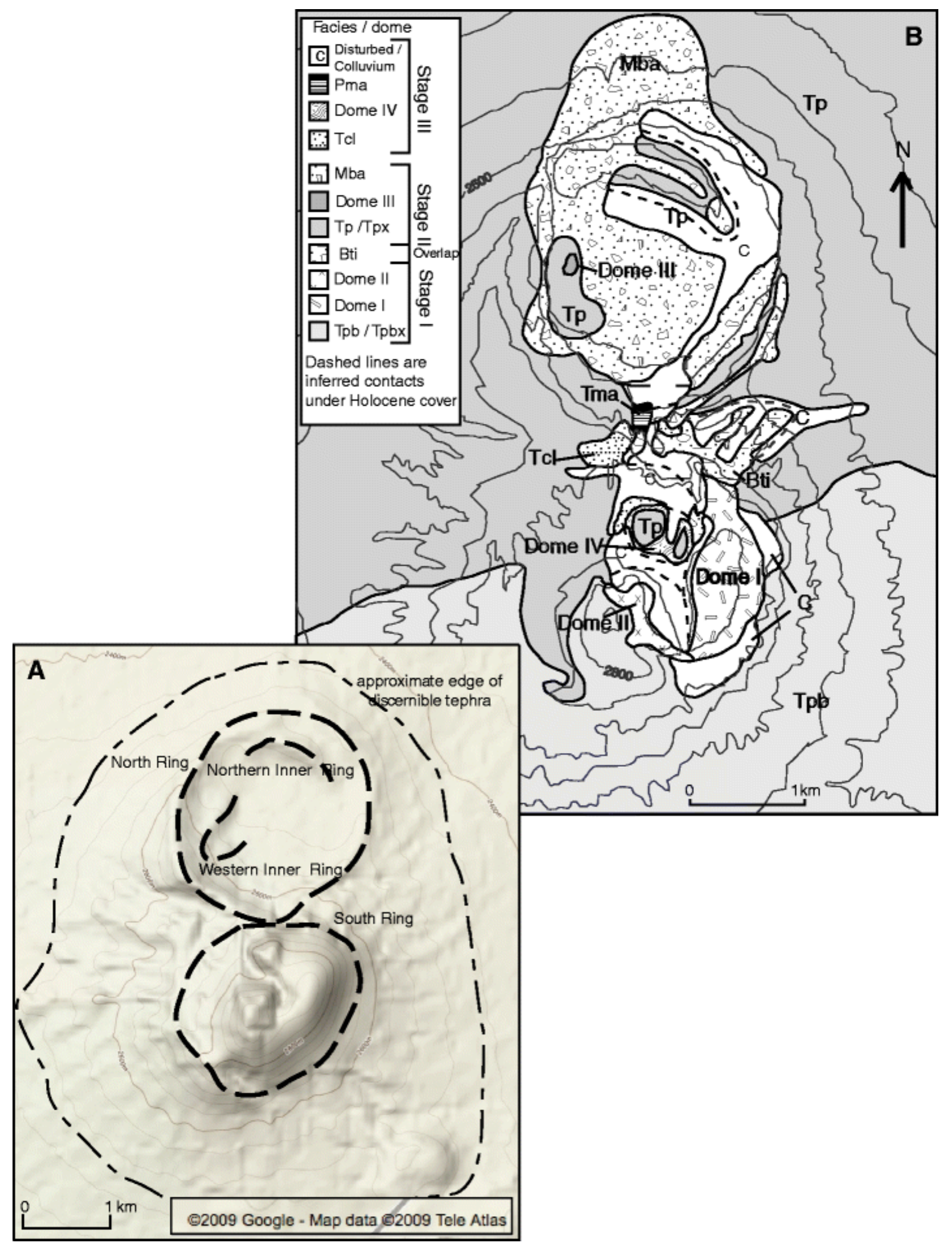


Fig. 2 Geologic map of Cerro Pinto based on major volcanic lithofacies and GoogleEarth $®$ image of Cerro Pinto showing tuff ring rims. The quarry is located at the junction of the north and south rings

Lithofacies at Cerro Pinto comprise lava and volcaniclastic rocks. Many facies are deposits that only occur in one place, as products of a single, central-vent eruption. Facies are described in detail in Tables 1 and 2.

Table 1 Lithologic descriptions of the domes

\begin{tabular}{|c|c|c|c|c|}
\hline Dome & Sample description & Volume* & Location & $\begin{array}{l}\text { Associated mass- } \\
\text { flow deposits }\end{array}$ \\
\hline \begin{tabular}{|l|l|} 
Dome \\
I
\end{tabular} & $\begin{array}{l}\text { Massive, pink-grey to white rhyolite with }<5 \\
\text { mm subhedral phenocrysts of biotite }(<1 \%), \\
\text { sanidine (<1\%), and plagioclase }(2 \%) \text { in } \\
\text { glassy groundmass. Autobreccia clasts have a } \\
\text { glassy shell and a pumiceous } \\
\text { cryptocrystalline interior. Biotite and } \\
\text { plagioclase phenocrysts are commonly } \\
\text { intergrown. Microlitic clasts are entrained in } \\
\text { the glassy matrix. }\end{array}$ & $0.26 \mathrm{~km}^{3}$ & $\begin{array}{l}\text { Eastern half } \\
\text { of the } \\
\text { southern } \\
\text { tuff ring }\end{array}$ & $\begin{array}{l}\text { Block-and-ash- } \\
\text { flow deposits } \\
\text { down two major } \\
\text { paleo-drainages; } \\
\text { multiple debris- } \\
\text { flow deposits. }\end{array}$ \\
\hline \begin{tabular}{|l|} 
Dome \\
II
\end{tabular} & $\begin{array}{l}\text { Stony blue and orange flow-banded rhyolite. } \\
\text { The bands are } 5-20 \mathrm{~mm} \text { thick. Euhedral } \\
\text { phenocrysts }(<1.5 \mathrm{~mm}) \text { of plagioclase }(3 \%) \text {, } \\
\text { quartz }(1 \%) \text {, sanidine }(<1 \%) \text {, and biotite } \\
\text { (1\%). Trachytic groundmass is dominated by } \\
\text { plagioclase microlites with rare zircon } \\
\text { microphenocrysts. }\end{array}$ & $0.21 \mathrm{~km}^{3}$ & $\begin{array}{l}\text { South- } \\
\text { western part } \\
\text { of the } \\
\text { southern } \\
\text { tuff ring }\end{array}$ & $\begin{array}{l}\text { Rare debris-flow } \\
\text { deposits to the } \\
\text { south and west of } \\
\text { the dome. }\end{array}$ \\
\hline \begin{tabular}{l|l} 
Dome \\
III
\end{tabular} & $\begin{array}{l}\text { Sugary grey stony rhyolite with subhedral } \\
\text { phenocrysts }(<2.5 \mathrm{~mm}) \text { of biotite }(<1 \%) \text {, } \\
\text { quartz }(<1 \%) \text {, plagioclase }(2 \%) \text {, and sanidine } \\
\text { (<1\%). Lava is punky and altered. } \\
\text { Groundmass is trachytic with microlitic } \\
\text { plagioclase and microphenocrysts of zircon. } \\
\text { Phenocrysts are commonly intergrown. }\end{array}$ & $\begin{array}{l}0.025 \\
\mathrm{~km}^{3}\end{array}$ & $\begin{array}{l}\text { West- } \\
\text { central edge } \\
\text { of the } \\
\text { northern } \\
\text { tuff ring }\end{array}$ & Explosion breccia \\
\hline \begin{tabular}{|l|l} 
Dome \\
IV
\end{tabular} & $\begin{array}{l}\text { Massive sugary white rhyolite with } \\
\text { plagioclase and biotite phenocrysts up to } 2.2 \\
\text { mm in diameter. Microphenocrysts of } \\
\text { plagioclase, zircon, and biotite are found } \\
\text { sporadically in the groundmass. Includes } \\
{ }^{40} \mathrm{Ar}{ }^{39} \mathrm{Ar} \text { dated sample, PIN02-6. }\end{array}$ & $0.04 \mathrm{~km}^{3}$ & $\begin{array}{l}\text { Northern } \\
\text { edge of the } \\
\text { southern } \\
\text { tuff ring }\end{array}$ & $\begin{array}{l}\text { One block-and- } \\
\text { ash-flow deposit } \\
\text { and single } \\
\text { pyroclastic-flow } \\
\text { deposit. }\end{array}$ \\
\hline
\end{tabular}

*Volumes estimated using cuboid morphology with base elevation roughly equal to the surrounding bedrock 
Table 2 Lithofacies descriptions

\begin{tabular}{|c|c|c|}
\hline Facies & Description & Interpretation \\
\hline $\begin{array}{l}\text { Tp / Tpb: Pumiceous } \\
\text { tephra and biotite-rich } \\
\text { pumiceous tephra; } \\
\text { subfacies Tpx and } \\
\text { Tpbx }<15 \% \text { of facies. }\end{array}$ & $\begin{array}{l}\text { Clast-supported, well-bedded deposits with } \\
\text { plane-parallel laminations of ash to angular } \\
\text { lapilli. Bedding thickness } 0.1-40 \mathrm{~cm} \text {; } \\
\text { preserved deposit thickness } \sim 50 \text { m; thickness } \\
\text { to pre-eruptive bedrock } \sim 150 \mathrm{~m} \text {. Rare normal } \\
\text { grading; well sorted. Accretionary lapilli } \\
\text { common in some beds. Composed of } \\
\text { moderately vesiculated white rhyolite and } \\
\text { pumice ( } \sim 5 \%) \text {, stony banded rhyolite } \\
\text { ( } 25 \%) \text {, and perlite }(\sim 10 \%) \text { clasts } 0.2-3 \mathrm{~cm} \\
\text { in a sparse coarse-ash matrix. Outsized clasts } \\
\text { rare. Phenocryst assemblage includes } \\
\text { subhedral crystals of quartz, plagioclase, } \\
\text { sanidine, and biotite up to } 1.75 \text { mm in } \\
\text { diameter. Small zircons ( }<0.05 \text { mm) make up } \\
\sim 1 \% \text { of the groundmass. Phenocryst } \\
\text { intergrowth is common between quartz and } \\
\text { biotite and quartz and sanidine. Tpb is } \\
\text { distinguished from Tp by the abundance of } 2- \\
3 \% \text { biotite phenocrysts in hand sample. } \\
\text { Tpbx/Tpx: cross-bedding and beds of small- } \\
\text { amplitude starved ripples common locally. } \\
\text { On the south flank of the south ring, Tpbx is } \\
\text { fine to coarse ash and lapilli with <10-cm- } \\
\text { thick lensoidal beds of angular stony blue and } \\
\text { grey rhyolite clasts up to } 5 \text { cm in diameter. }\end{array}$ & $\begin{array}{l}\text { Fallout-dominated with } \\
\text { some surge deposits (-x } \\
\text { facies) originating from } \\
\text { the north ring (Tp) and } \\
\text { from the south ring (Tpb). }\end{array}$ \\
\hline Tcl: Cross-bedded & $\begin{array}{l}\text { Clasts are fin ash to lapilli; average grain size } \\
\text { is coarse ash; lapilli } 1-2.5 \mathrm{~cm} \text {. Bedding } \\
\text { structures include tangential cross-bedding, } \\
\text { tabular forsets, antidunes, and bomb sags. } \\
\text { Beds are poorly to moderately sorted with } \\
\text { reverse or no grading. Beds are } 1.5-70 \mathrm{~cm} \\
\text { thick. Tcl deposits commonly scour into } \\
\text { underlying deposits and truncate other Tcl } \\
\text { beds. Some massive ash beds have } \\
\text { accretionary lapilli. Local fine laminations are } \\
\text { moderately well-sorted clasts. Clasts are } \\
\text { white stony rhyolite }(\sim 45 \%), \text { pumiceous } \\
\text { white rhyolite ( } 25 \%), \text { lithic clasts }(\sim 25 \%) \\
\text { and banded stony rhyolite }(\sim 5 \%) \text {. Basement } \\
\text { clasts include granite, andesite, green schist, } \\
\text { and minor limestone. Oxide rings are } \\
\text { common surrounding lithic clasts. Outsized }\end{array}$ & $\begin{array}{l}\text { "Wet" pyroclastic- surge } \\
\text { dominated with few } \\
\text { fallout beds }\end{array}$ \\
\hline
\end{tabular}




\begin{tabular}{|c|c|c|}
\hline Facies & Description & Interpretation \\
\hline & $\begin{array}{l}\text { clasts are common }(<25 \mathrm{~cm}) \text {. Rhyolite clasts } \\
\text { contain occasional phenocrysts of biotite and } \\
\text { plagioclase. }\end{array}$ & \\
\hline $\begin{array}{l}\text { Tma: Massive ash- } \\
\text { rich tephra }\end{array}$ & $\begin{array}{l}\text { Massive, matrix-supported, moderately } \\
\text { sorted, channel-confined bed } 1-15 \text { m thick. } \\
\text { Coarsely laminated beds present in upper } \\
\text { portion of the deposit. Clasts } ~ 5 \% \text {, stony } \\
\text { white rhyolite, white pumice, banded rhyolite, } \\
\text { perlite, and lithic clasts (andesite and granite). } \\
\text { Fe oxidation rims common around basement } \\
\text { lithic clasts. Matrix is composed of fine to } \\
\text { medium ash particles. Clasts are } 0.2-2 \mathrm{~cm} \text { in } \\
\text { diameter with outsized clasts as large as } 25 \\
\text { cm. Normally graded with respect to lithic } \\
\text { clasts and reversely graded with respect to } \\
\text { pumice clasts. }\end{array}$ & $\begin{array}{l}\text { Pyroclastic density } \\
\text { current deposit }\end{array}$ \\
\hline Bp: polylithic breccia & $\begin{array}{l}\text { Massive, clast-supported, reversely graded, } \\
\text { and poorly sorted polylithic (Bp) beds of } \\
\text { blocks and lapilli with a coarse to fine ash } \\
\text { matrix. Beds are } 10-150 \mathrm{~cm} \text { thick. Coarse } \\
\text { clasts locally define weak cross bedding. } \\
\text { Polylithic breccia contains a mixture of } \\
\text { banded blue and gray lava, stony white lava, } \\
\text { and white pumice. Matrix contains } \\
\text { phenocrysts }<3 \mathrm{~mm} \text { of plagioclase }(2 \%) \text { and } \\
\text { biotite }(2 \%) \text {. Clasts in both up to } 50 \mathrm{~cm} \text { in } \\
\text { diameter. }\end{array}$ & $\begin{array}{l}\text { Semi-cooled block-and- } \\
\text { ash flow }\end{array}$ \\
\hline \multicolumn{3}{|l|}{ Facies Associations } \\
\hline $\begin{array}{l}\text { Bti: interstratified } \\
\text { breccia and tephra }\end{array}$ & $\begin{array}{l}\text { Interbedded facies Bp and facies Tp. Beds of } \\
\text { Bp undulate; beds of } \mathrm{Tp}<10 \mathrm{~cm}-1 \mathrm{~m} \text { thick } \\
\text { pinch and swell, merge with coherent Tp beds } \\
\text { laterally }\end{array}$ & $\begin{array}{l}\text { Complex interaction of } \\
\text { block-and-ash flow from } \\
\text { unstable domes and surge } \\
\text { / fall from pyroclastic } \\
\text { eruptions }\end{array}$ \\
\hline $\begin{array}{l}\text { Mba: breccia and } \\
\text { tephra succession }\end{array}$ & $\begin{array}{l}\text { Three-part succession of ash-matrix- } \\
\text { supported breccias overlain by clast- } \\
\text { supported breccia. Upper breccia gradational } \\
\text { into cross-bedded, fine-grained tephra with } \\
\text { rare bomb-sag structures and accretionary } \\
\text { lapilli. Deposit varies from } \sim 10 \mathrm{~cm} \text { to } \sim 2 \mathrm{~m} \text { in } \\
\text { thickness. }\end{array}$ & $\begin{array}{l}\text { Interplay of ballistic } \\
\text { clasts, fallout, pyroclastic } \\
\text { surges, and high winds } \\
\text { during dome destruction. }\end{array}$ \\
\hline
\end{tabular}




\section{Lava Domes}

The four domes at Cerro Pinto are chemically similar, but differ in mineral assemblages and / or in the relative abundance and size of phenocrysts. Petrologic variation within an individual dome is small to non-existent. The four domes have a combined volume of $\sim 0.5 \mathrm{~km}^{3}$ (Table 1). The domes are generally steep sided and surrounded by thick aprons of talus while the tops are flat to rounded and covered in places by dense vegetation. All three domes rise to approximately the same elevation (3000 m.a.s.l.) and are separated from one another by steep, 100-150 m deep ravines. Dome facies comprise stony rhyolite, in which the glassy groundmass is partially to wholly devitrified, vitrophyre, in which glass is largely preserved, and autobreccia, which may be made up of either stony rhyolite or vitrophyre clasts. The stony rhyolite commonly exhibits sugary texture and is only occasionally flow banded.

\section{Volcaniclastic Rocks}

Volcaniclastic deposits (Table 2) comprise primary and reworked pyroclasts. These form the bulk of the tuff ring-dome complex and nearly the entirety of the north ring. Pyroclastic deposits from Cerro Pinto cover approximately $220 \mathrm{~km}^{2}$ (Garcia-Banda 1984 ) and are as much as $150 \mathrm{~m}$ thick. The primary volcaniclastic lithofacies at Cerro Pinto are biotite-pumice tephra, pumice tephra, cross-bedded lithic-lapilli tephra, massive ash-rich tephra, and polylithic breccia. Facies associations are interbedded breccia and tephra and successions of mixed breccia types. Tephra produced during different eruptive stages are distinguished from one another, where possible, by phenocryst types, sizes, and abundances.

Pumice tephra (Facies Tp; subfacies Tpx) \& Biotite-Pumice Tephra (Facies Tpb; subfacies Tbpx)

The majority of deposits at Cerro Pinto are pumice- and biotite-pumice tephra (Facies Tp, Tpb; Figs. 2 and 3a, b). These facies dominate distal deposits of the northern and southern tuff rings. The deposits are discrete and single thin beds $(<5 \mathrm{~cm})$ can be traced over $100 \mathrm{~m}$ of continuous exposure. Cross-bedded subfacies Tpbx and Tpx are exposed in drainages proximal to the southern and northern tuff rings respectively. Several ravines on the southern flank of the south tuff ring contain 5-10 m-thick beds of facies Tpbx. The subfacies have similar clast composition to the main Tp and Tpb facies, however, bedding structures in the subfacies are more complex, including tabular forests and tangential cross-bedding (Fig. 3d). 

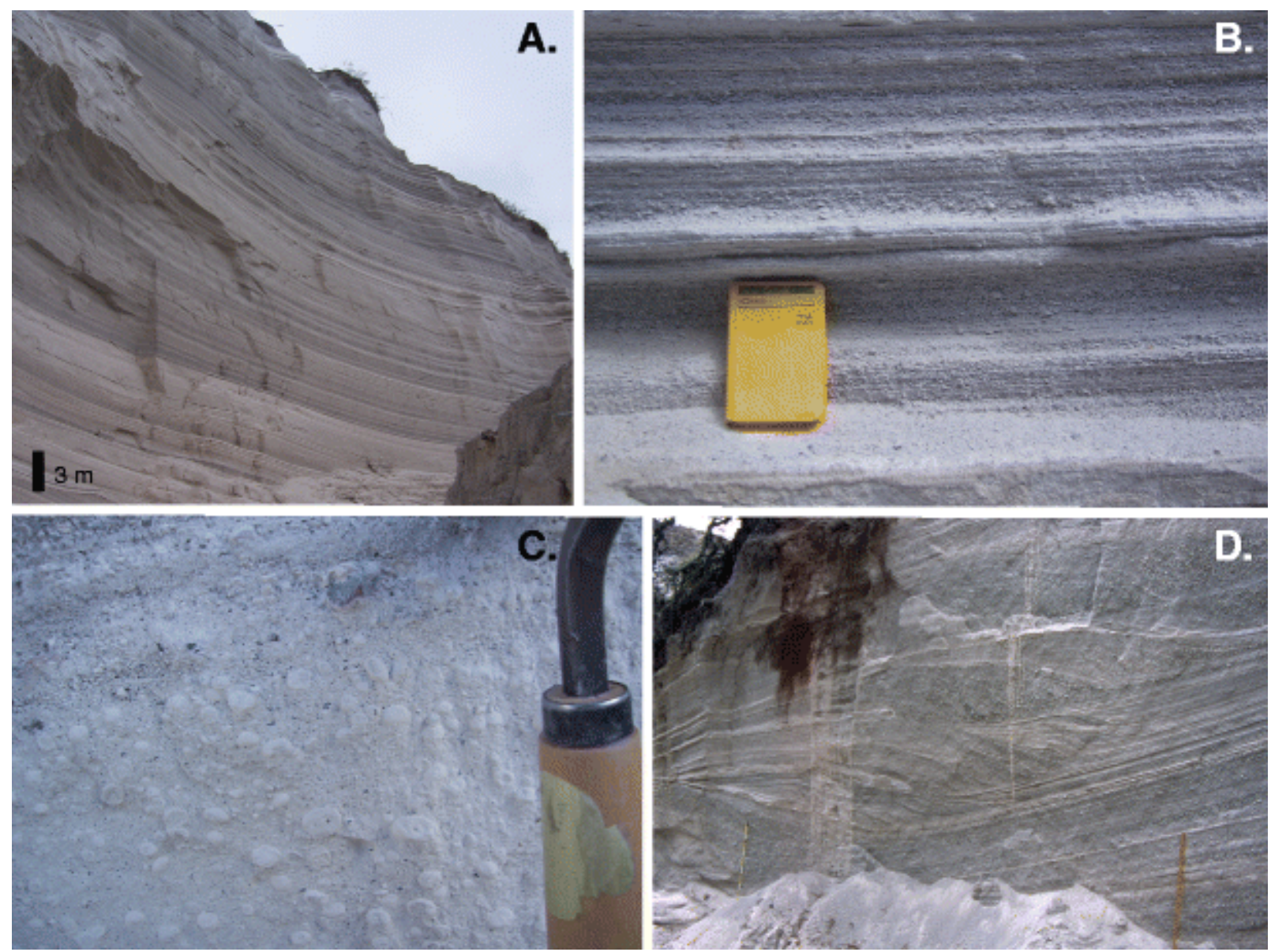

Fig. 3 a \& b. Fallout dominated tephra deposits of facies Tp. C. Accretionary lapilli within facies Tcl. D. Thick cross-bedded deposits representative of subfacies Tpbx

\section{Cross-bedded lithic-rich tephra (facies Tcl)}

Facies Tcl is commonly found in small volumes at the base of Tp and Tpb deposits. Tcl deposits are moderately sorted with an abundance of cross-bedding structures such as tangential cross-bedding, tabular forests and antidunes, and accretionary lapilli (Fig. $3 c$ ). The Tcl facies is differentiated from the Tpx and Tpbx facies by the prevalence $(-25 \%)$ of basement lithic clasts of granite, andesite, limestone, and green schist, and hydrothermally altered stony rhyolite clasts. Tcl deposits are thin, ranging from 1-10 m with individual beds up to10 centimeters thick.

Massive ash-rich tephra (facies Tma)

Facies Tma (Fig. 4) is exposed in one outcrop, approximately $200 \mathrm{~m}$ north of Dome II (Fig. 2). The deposit is $\sim 10 \mathrm{~m}$ thick and apparently fills a paleochannel in deposits of 
facies Tp. Most of the deposit is weakly stratified with outsized clasts of pumice and rare lithic clasts. The upper $3 \mathrm{~m}$, however, are well stratified and contain large $(<10 \mathrm{~cm})$ blocks of pumice.

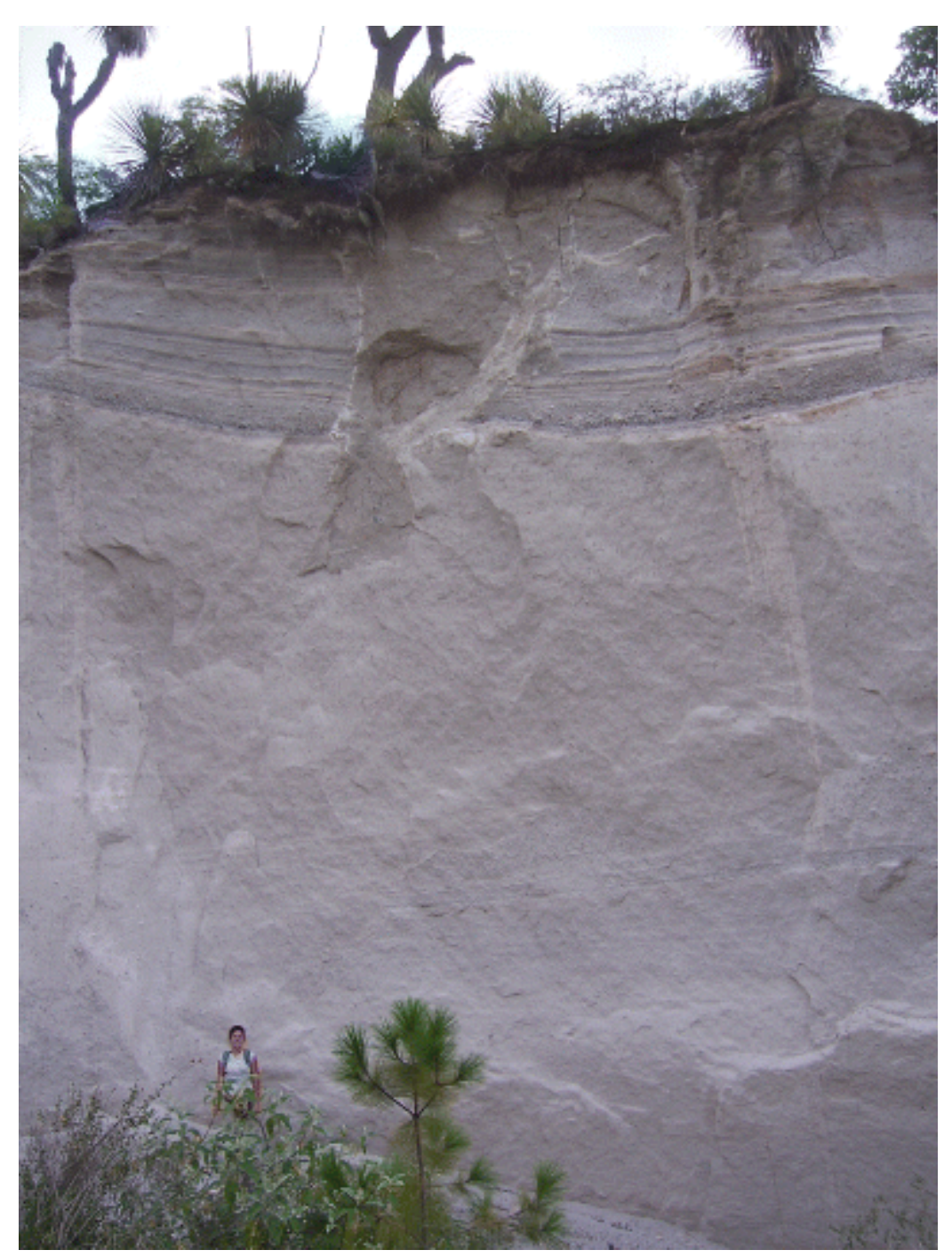

Fig. 4 Pyroclastic density-current deposits (Facies Tma). Although dominantly massive, deposit is faintly stratified at a few levels with rafted pumices (note above and to right of geologist's head) and well stratified in the upper 3 meters

Polylithic breccia (Bp)

Facies $\mathrm{Bp}$ is exposed only in association with horizons of facies $\mathrm{Tp}$ (facies association Bti described below) and is confined to paleodrainages proximal to domes. Clasts include large blocks of banded, sugary, and pumiceous rhyolite in a coarse-grained, phenocryst-rich matrix. 


\section{Facies Associations}

Several deposits at Cerro Pinto comprise facies associations. In some cases these deposits reflect different depositional mechanisms that were on-going simultaneously. Elsewhere, a diverse succession of facies reflects complex processes as part of a single eruptive episode.

\section{Interbedded breccia and tephra (facies association Bti)}

The facies association Bti (Fig. 5) comprises interbedded breccia (facies Bp) and ash beds (facies Tp). These deposits are found only within $400 \mathrm{~m}$ of the domes and have lobate morphology. Breccia beds are 1-5 m thick, and commonly lens out laterally. Clasts are identical in mineralogy, color, and texture to intact Dome I material, and are inferred to be derived from it. Interbedded facies Tp beds are discrete, $\mathrm{mm}$ to $1 \mathrm{~m}$-thick beds of coarse ash and crystals of plagioclase and occasional quartz. The tephra lenses are not parallel with one another but rather mimic the weak tangential internal bedding structures of the breccia deposits. The lenses are thinly bedded with parallel laminations, and extend far into the deposit from edges where they merge into coherent Tp deposits.
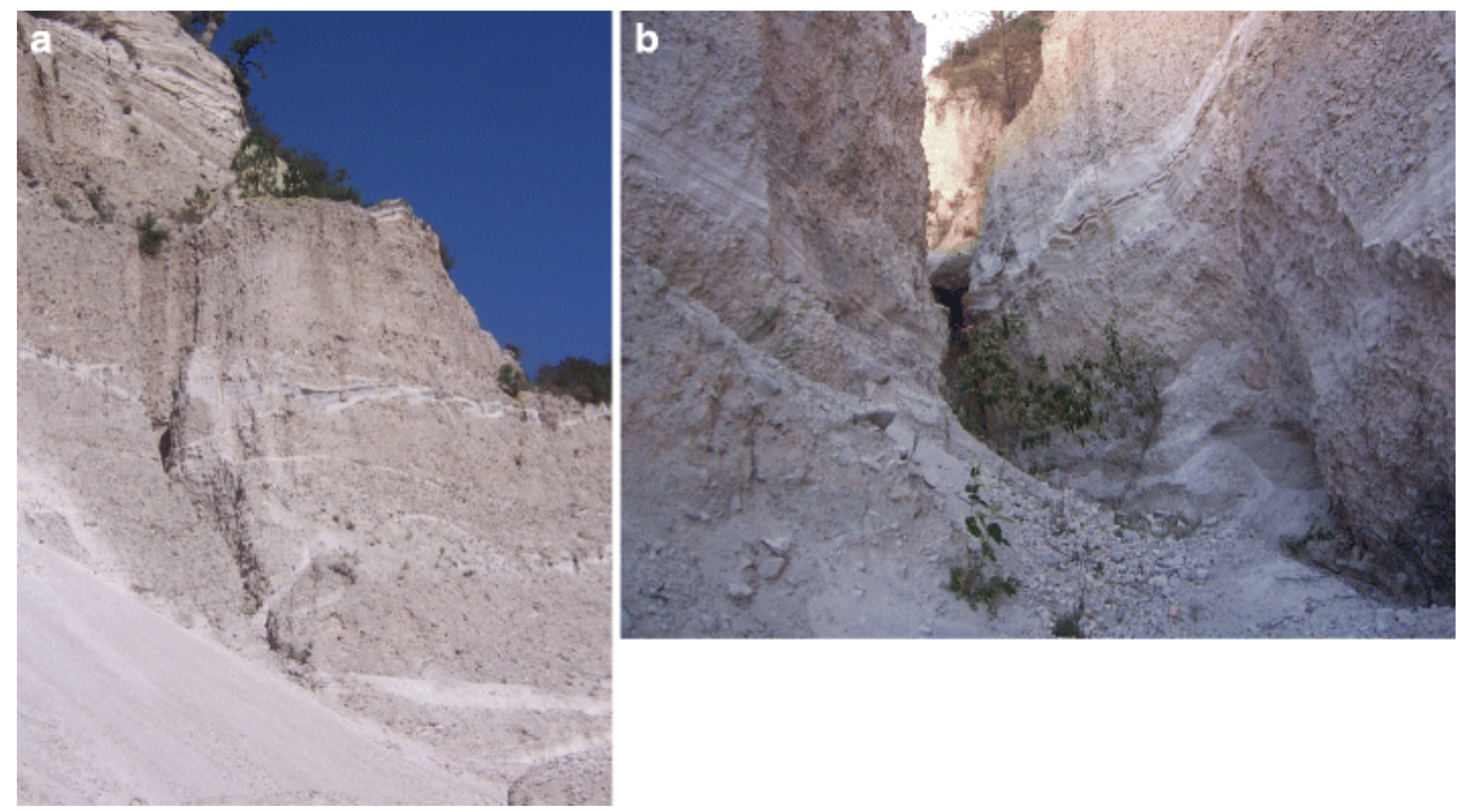

Fig. 5 Facies association Bti. Beds of polylithic breccia are 1-5 m thick; fine ash beds are parallel to weak bedding in breccia. In $\mathrm{B}$, note that fine-grained material of facies Tp extends to base of exposure 
The monolithic breccia and ash, facies association Mba, is a three-part deposit that comprises matrix- to clast-supported breccia overlain by cross-bedded tephra (Fig. 6). This succession is up to $1 \mathrm{~m}$ thick within the northern tuff ring and over its northern rim and greater than $2.5 \mathrm{~m}$ thick on the northeast flank of the north tuff ring (Fig. 2). It consists of a lower, ash-rich member, a middle, ash-poor member, and an upper, crossbedded member. The lower member is light grey and matrix supported with $\sim 85 \%$ clasts and $15 \%$ coarse ash, and is as much as $1 \mathrm{~m}$ thick, but is not exposed within the north tuff ring. Clasts are dominantly $1-5 \mathrm{~cm}$, but the bed is bimodally sorted due to the ash component. The middle member is clast supported with $98 \%$ clasts and only $2 \%$ ash, and is less than $2 \mathrm{~m}$ thick. Outsize clasts are $15-20 \mathrm{~cm}$, but overall the sorting is moderately good (Fig. 6a), with clast support on $2-5-\mathrm{cm}$ fragments. The bedding structures are weak in the two lower members and only locally identifiable in the outcrop. The upper member comprises cross-bedded coarse ash and lapilli beds as much as $50 \mathrm{~cm}$ thick with rare block sags and accretionary lapilli.

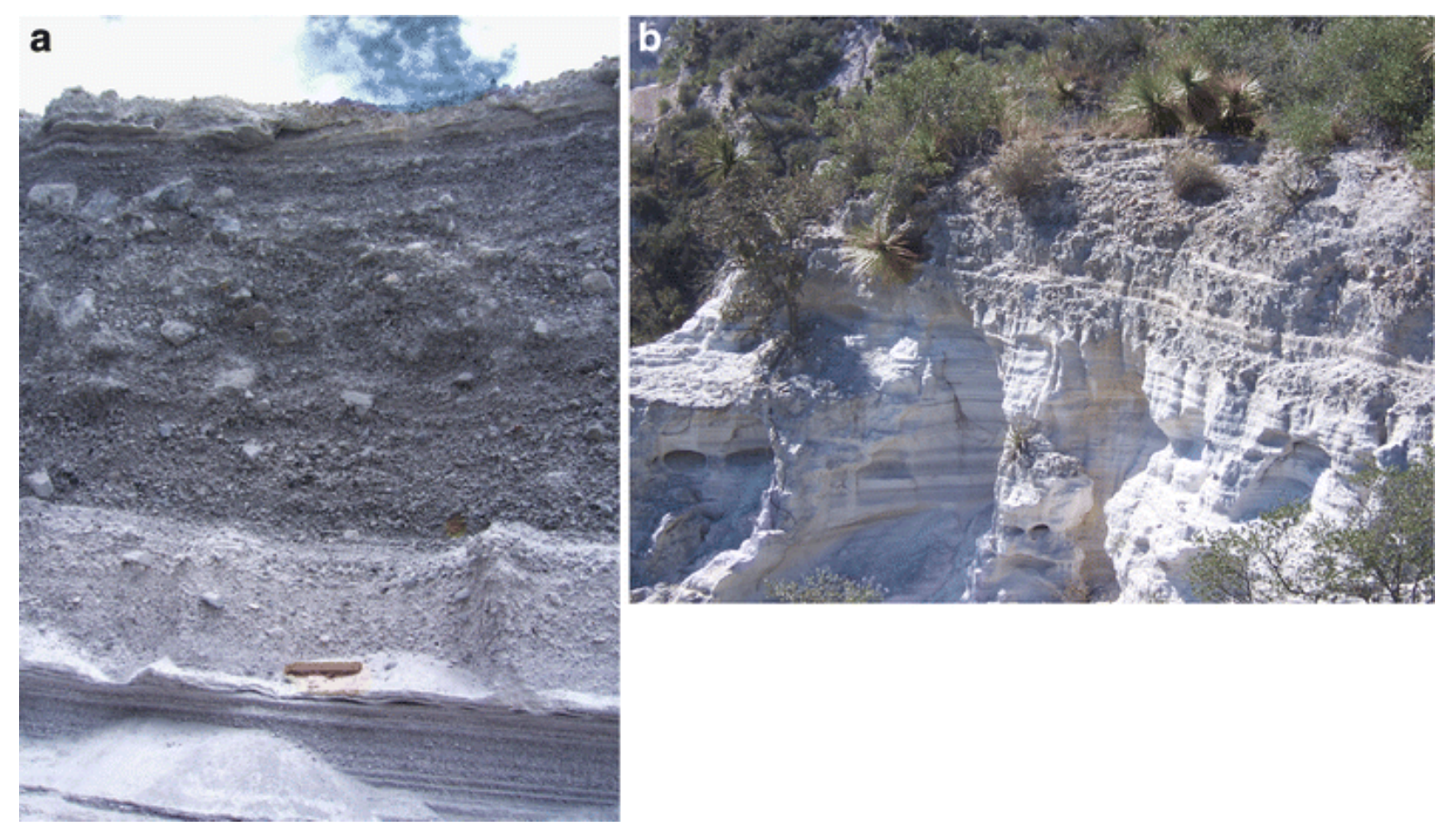

Fig. 6 Facies association Mba. a. At its thickest location, Mba comprises a basal unit $\sim 60 \mathrm{~cm}$ thick and a middle unit approximately $1.3 \mathrm{~m}$ thick, which together are interpreted as emplaced by strong winds and heavy fall, and an upper surge unit. b. Mba overlying fine-grained fall deposits of facies Tp on rim of north ring and shows distinct stratification 


\section{Quaternary Deposits (Facies C)}

Quaternary deposits in the north ring comprise loess deposits that have been reworked by farming and colluvium. In the south ring, massive, poorly sorted breccias that fringe Domes I, II, and IV in some areas and fill in modern drainages are interpreted as Holocene debris-flow deposits.

\section{Geochemistry}

Major-element concentrations derived from whole-rock geochemistry of eight juvenile clasts vary little throughout the dome complex (Table 3). Analyzed samples were juvenile pumice from the tuff rings and stony rhyolite from the domes. We collected samples representative of the south ring and domes I and II, the north ring, northern inner ring, western inner ring and dome III, and dome IV. All samples are high-silica rhyolite and are chemically and compositionally distinct from the larger volcanoes that mark the outer boundary of the Serdán-Oriental Basin (Riggs and Carrasco-Núñez 2004). The chemical homogeneity suggests that Cerro Pinto evolved from a single magma batch and tapped no additional magma sources during the course of the eruption. This is in agreement with a likely short-term period of activity for the whole tuff ring-dome complex.

Table 3 XRF major element data and ICP-MS trace element data for samples from Cerro Pinto. XRF geochemical analyses were performed on a Siemens 3000 at UNAM. Analytical procedures for major elements are described in Lozano-Santa Cruz et al. (1995). ICP-MS data were obtained on a VG Axiom ICP-MS at NAU. Sample locations are given in Universal Transverse Mercator (UTM) coordinates (NAD 83)

\begin{tabular}{|c|c|c|c|c|c|c|c|c|}
\hline \multirow[b]{2}{*}{$\begin{array}{l}\text { Major } \\
\text { Element } \\
\text { s Wt \% }\end{array}$} & Stage I & \multirow[b]{2}{*}{$\begin{array}{c}\text { Dome I } \\
658205 E \\
2142778 \\
N\end{array}$} & \multirow[b]{2}{*}{\begin{tabular}{|c} 
Dome II \\
$657623 E$ \\
2142806 \\
$\mathrm{~N}$
\end{tabular}} & \multirow[b]{2}{*}{\begin{tabular}{|c|} 
Stage II \\
North \\
Ring \\
$658904 E$ \\
2145221 \\
N \\
\end{tabular}} & \multirow[b]{2}{*}{$\begin{array}{l}\text { Northern } \\
\text { Inner } \\
\text { Ring } \\
657888 E \\
2145364 \\
\text { N }\end{array}$} & \multirow[b]{2}{*}{\begin{tabular}{|c} 
Western \\
Inner \\
Ring \\
657016E \\
2144364 \\
N
\end{tabular}} & \multirow[b]{2}{*}{\begin{tabular}{|c|} 
Dome III \\
657010E \\
2145016 \\
N
\end{tabular}} & \multirow[b]{2}{*}{\begin{tabular}{|c|} 
Stage III \\
Dome IV \\
657648E \\
2143007 \\
N \\
\end{tabular}} \\
\hline & \begin{tabular}{|c|} 
South \\
Ring 2 \\
656956 \\
E \\
141199 \\
N
\end{tabular} & & & & & & & \\
\hline $\mathrm{SiO}_{2}$ & 74.11 & 74.94 & 74.49 & 74.65 & 75.33 & 75.14 & 75.35 & 79.79 \\
\hline $\mathrm{TiO}_{2}$ & 0.03 & 0.03 & 0.03 & 0.02 & 0.03 & 0.03 & 0.03 & 0.03 \\
\hline $\mathrm{Al}_{2} \mathrm{O}_{3}$ & 13.94 & 14.01 & 14.13 & 13.92 & 13.93 & 13.89 & 14.12 & 19.76 \\
\hline $\mathrm{Fe}_{2} \mathrm{O}_{3}$ & 0.78 & 0.74 & 0.81 & 0.74 & 0.79 & 0.79 & 0.78 & 0.78 \\
\hline $\mathrm{MnO}$ & 0.11 & 0.11 & 0.08 & 0.11 & 0.11 & 0.11 & 0.11 & 0.11 \\
\hline MgO & 0.16 & 0.18 & 0.15 & 0.15 & 0.16 & 0.17 & 0.22 & 0.16 \\
\hline $\mathrm{CaO}$ & 0.50 & 0.52 & 0.56 & 0.51 & 0.53 & 0.52 & 0.53 & 0.51 \\
\hline
\end{tabular}




\begin{tabular}{|c|c|c|c|c|c|c|c|c|}
\hline \multirow[b]{2}{*}{$\begin{array}{l}\text { Major } \\
\text { Element } \\
\text { s Wt \% }\end{array}$} & \multirow[b]{2}{*}{\begin{tabular}{|c|} 
Stage I \\
South \\
Ring 2 \\
656956 \\
E \\
141199 \\
N \\
\end{tabular}} & \multirow[b]{2}{*}{$\begin{array}{c}\text { Dome I } \\
658205 E \\
2142778 \\
N\end{array}$} & \multirow[b]{2}{*}{$\begin{array}{l}\text { Dome II } \\
\text { 657623E } \\
2142806 \\
\text { N }\end{array}$} & \multirow[b]{2}{*}{\begin{tabular}{|c|} 
Stage II \\
North \\
Ring \\
$658904 E$ \\
2145221 \\
N \\
\end{tabular}} & \multirow[b]{2}{*}{$\begin{array}{l}\text { Northern } \\
\text { Inner } \\
\text { Ring } \\
657888 E \\
2145364 \\
\text { N }\end{array}$} & \multirow[b]{2}{*}{\begin{tabular}{|c} 
Western \\
Inner \\
Ring \\
657016E \\
2144364 \\
N
\end{tabular}} & \multirow[b]{2}{*}{\begin{tabular}{|c} 
Dome III \\
657010E \\
2145016 \\
N
\end{tabular}} & \multirow[b]{2}{*}{\begin{tabular}{|c|} 
Stage III \\
Dome IV \\
657648E \\
2143007 \\
N
\end{tabular}} \\
\hline & & & & & & & & \\
\hline $\mathrm{Na}_{2} \mathrm{O}$ & 4.46 & 4.48 & 4.47 & 4.43 & 4.50 & 4.53 & 4.55 & 4.40 \\
\hline $\mathrm{K}_{2} \mathrm{O}$ & 4.08 & 4.20 & 4.16 & 4.16 & 4.25 & 4.22 & 4.25 & 4.16 \\
\hline $\mathrm{P}_{2} \mathrm{O}_{5}$ & 0.05 & 0.05 & 0.05 & 0.06 & 0.05 & 0.05 & 0.06 & 0.05 \\
\hline LOI & 2.42 & 1.35 & 0.83 & 2.2 & 0.52 & 0.39 & 0.29 & 2.97 \\
\hline Total & 100.63 & 100.59 & 99.76 & 100.95 & 100.20 & 99.823 & 100.29 & 100.73 \\
\hline \multicolumn{9}{|c|}{ Rare Earth Elements (ppm) } \\
\hline $\mathrm{La}$ & 25 & 30 & 27 & 43 & 36 & 33 & 25 & 46 \\
\hline $\mathrm{Ce}$ & 23 & 27 & 24 & 34 & 31 & 30 & 23 & 38 \\
\hline $\operatorname{Pr}$ & 16 & 19 & 17 & 23 & 21 & 21 & 17 & 25 \\
\hline $\mathrm{Nd}$ & 13 & 16 & 14 & 19 & 17 & 18 & 15 & 21 \\
\hline $\mathrm{Pm}$ & 15 & 17 & 15 & 20 & 18 & 19 & 17 & 22 \\
\hline $\mathrm{Sm}$ & 16 & 18 & 16 & 21 & 19 & 20 & 18 & 22 \\
\hline $\mathrm{Eu}$ & 0 & 1 & 0 & 1 & 0 & 1 & 0 & 2 \\
\hline $\mathrm{Gd}$ & 3 & 4 & 2 & 10 & 0 & 7 & 4 & 16 \\
\hline $\mathrm{Tb}$ & 9 & 7 & 8 & 10 & 10 & 11 & 10 & 10 \\
\hline Dy & 10 & 9 & 0 & 3 & 12 & 14 & 13 & 14 \\
\hline Ho & 7 & 6 & 7 & 9 & 8 & 10 & 9 & 10 \\
\hline Er & 9 & 8 & 8 & 11 & 10 & 12 & 11 & 12 \\
\hline $\mathrm{Tm}$ & 8 & 7 & 8 & 11 & 10 & 11 & 11 & 11 \\
\hline $\mathrm{Yb}$ & 10 & 9 & 9 & 12 & 11 & 13 & 12 & 13 \\
\hline $\mathrm{Lu}$ & 9 & 8 & 9 & 11 & 10 & 12 & 11 & 12 \\
\hline
\end{tabular}

Other high-silica rhyolite volcanoes are present within the Serdán-Orientál Basin (e.g. Las Derrumbadas, Siebe and Verma 1988; Cerro Pizarro, Riggs and Carrasco-Núñez 2004; Tepexitl Maar, Austin-Erickson 2007). The rhyolites are generally similar to Cerro Pinto for $\mathrm{Al} 2 \mathrm{O} 3$ and $\mathrm{CaO}$ (Fig. 7a), but are scattered for the other major elements (Fig. $7 b$ ). The volcano most similar in chemical composition to Cerro Pinto is Tepexitl maar, a small rhyolitic volcano located southeast of Cerro Pinto and directly to the south of Las Derrumbadas (Fig. 1). Cerro Pinto and Tepexitl are significantly different in $\mathrm{FeO}, \mathrm{CaO}$, and $\mathrm{MgO}$, but both volcanoes may have drawn from the same original deep magma source before separating and fractionating in the upper crust. 

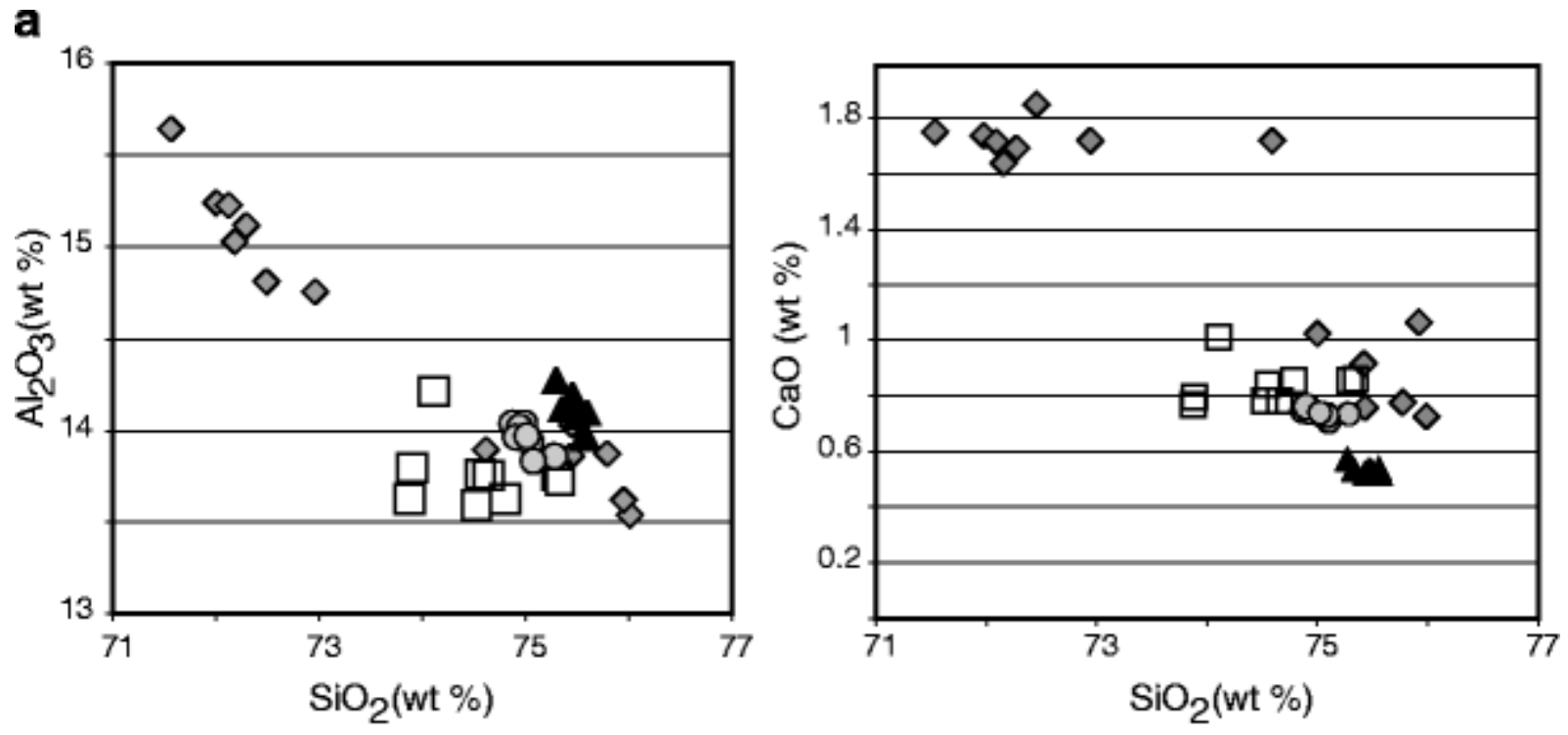

\section{$\diamond$ Derrumbadas rhyolite $\boldsymbol{\Delta}$ Cerro Pinto \\ $\square \quad$ Cerro Pizarro \\ Tepexitl Maar}

b
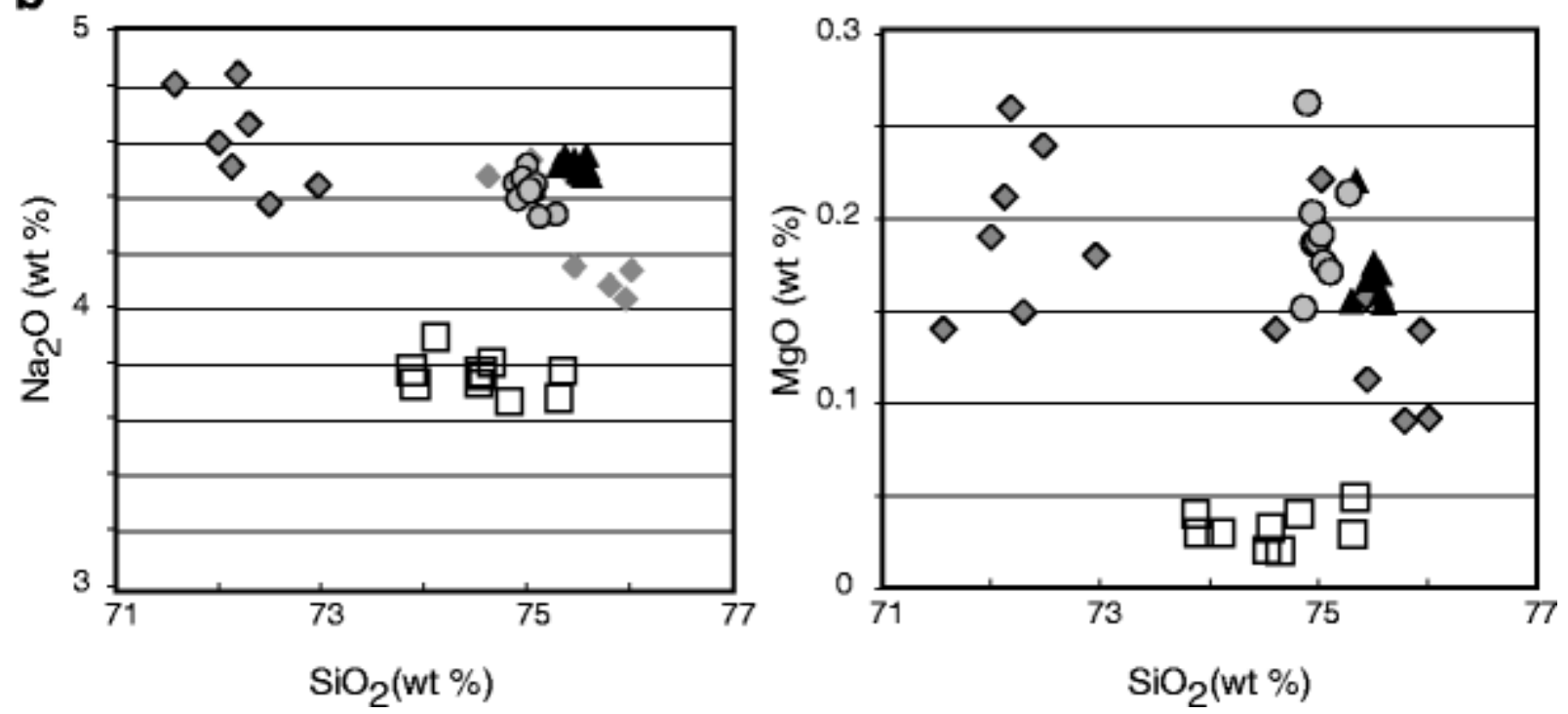

Fig. 7 Geochemical variation diagrams. a. A comparison of $\mathrm{Al} 2 \mathrm{O} 3$ and $\mathrm{CaO}$ vs. $\mathrm{SiO} 2$ shows that the smaller volcanoes in the Serdán-Orientál basin (see Fig. 1 for locations) are similar; Las Derrumbadas has distinctly different trends in lower-SiO2 rocks. b. Na2O and $\mathrm{MgO}$ values are similar between Tepexitl maar, Cerro Pinto, and the high-silica rocks of Las Derrumbadas

A plot of rare earth elements normalized to chrondrite (Fig. 8) shows little variation between elements, and the clear negative Eu anomaly suggests that differentiation in the source melt occurred at shallow levels $(<30 \mathrm{~km})$. Based on the narrow range of 
geochemical data, it is inferred that Cerro Pinto was produced by an eruption from a small magma batch separate from any of the other volcanoes in the basin.

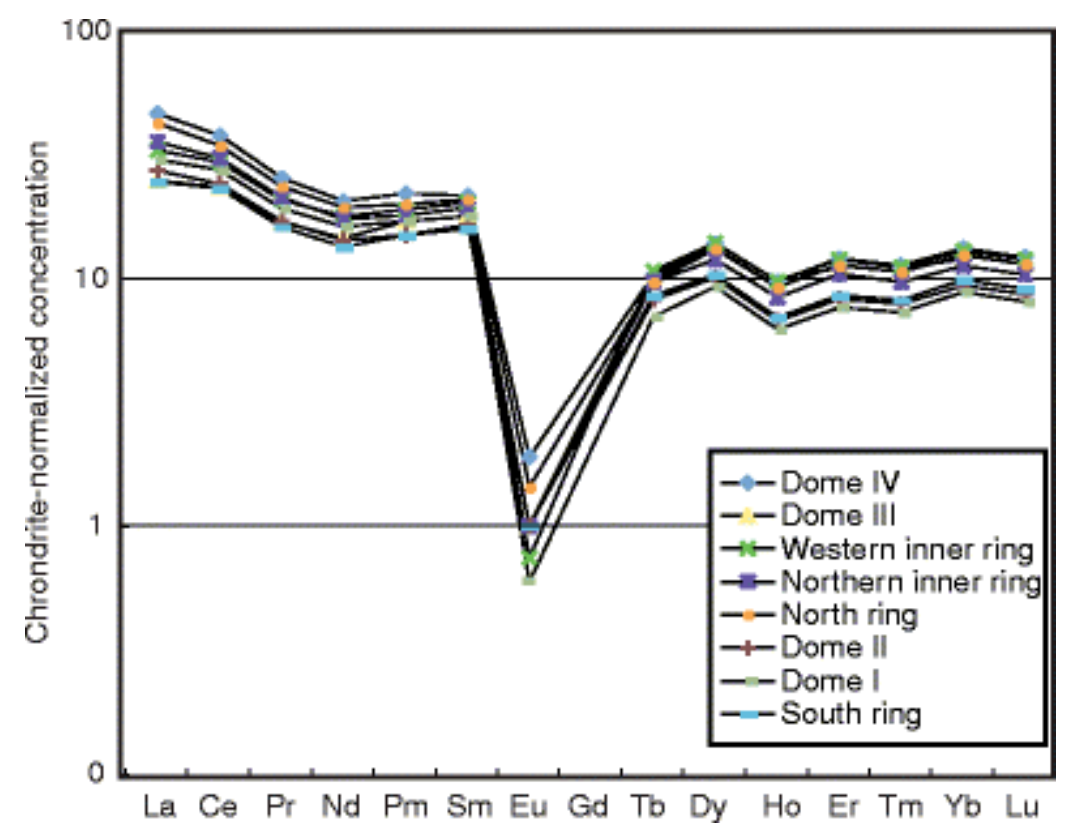

Fig. 8 Rare earth element "spidergram", with concentrations normalized to chondrite (Sun and McDonough 1989)

\section{Stage I-South Ring Activity}

Volcanic activity began with the explosive formation of the south tuff ring (Fig. 9a; $\sim 0.35$ $\mathrm{km}^{3}$ DRE erupted material) that deposited tephra onto a landscape of middle-Tertiary plutonic rock and Cretaceous limestone. Facies Tpb and Tpbx were emplaced simultaneously though the depositional mechanisms were different. Well-sorted, clastsupported biotite-pumice tephra (Tpb) was predominately emplaced by fallout and makes up the majority of the southern ring's volume. However, at several exposures in ravines on the ring flanks, cross-bedded subfacies Tpbx is exposed. The Tpbx subfacies represent pyroclastic surge deposits that played a minor role in the south ring's evolution. We envision that episodic explosions produced pyroclastic surges amidst a constant rain of fallout from a stable sub-plinian eruption column. Along the southern flank of the southern tuff ring, facies Tpbx makes up a greater percentage of the total volume of deposits suggesting that either the surges were preferentially directed to the south or the prevailing wind direction was from the south directing the more fallout to the north. The presence of thin planar beds and the absence of accretionary lapilli, bomb sags, or other forms of soft-sediment deformation indicates that most of the surge deposits were emplaced by pyroclastic currents too hot for condensation of water (cf. Chough and Sohn 1990) or from surges produced by lower water/magma ratios. 


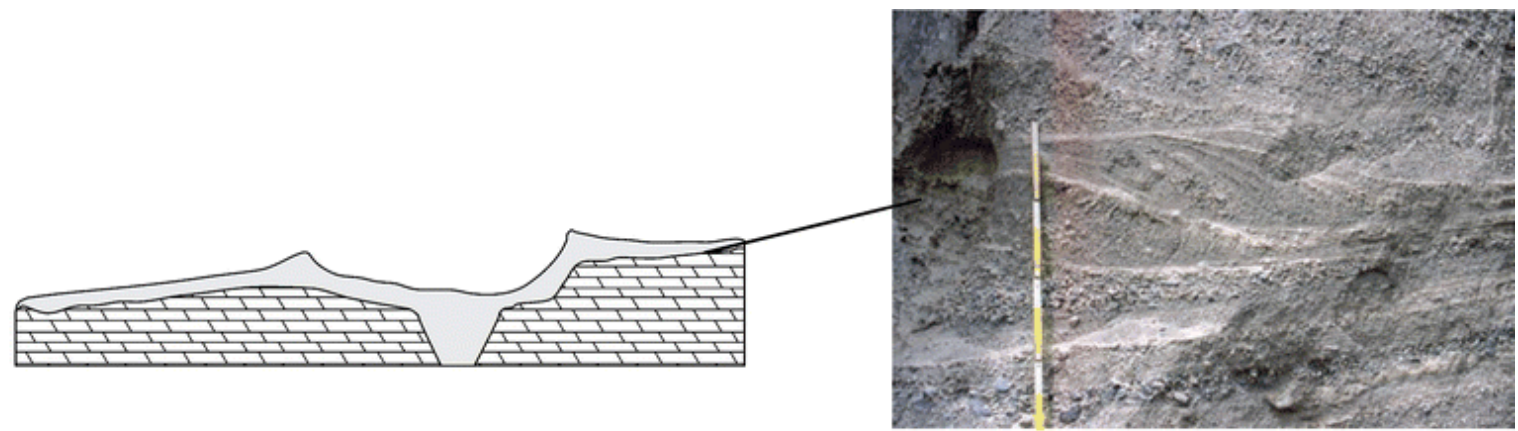

b

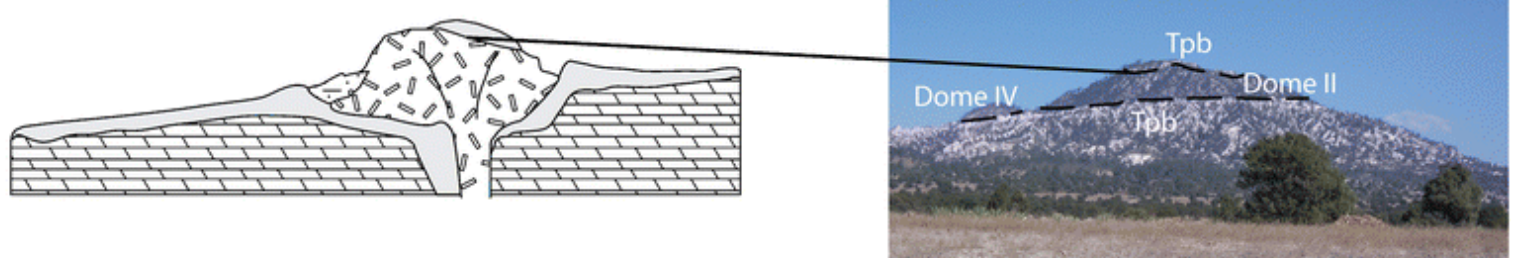

C

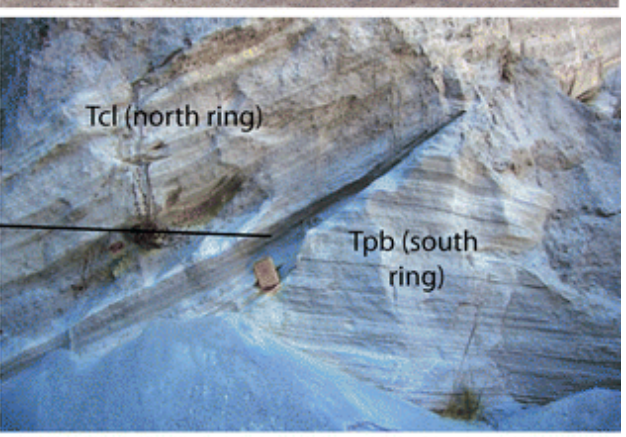

d

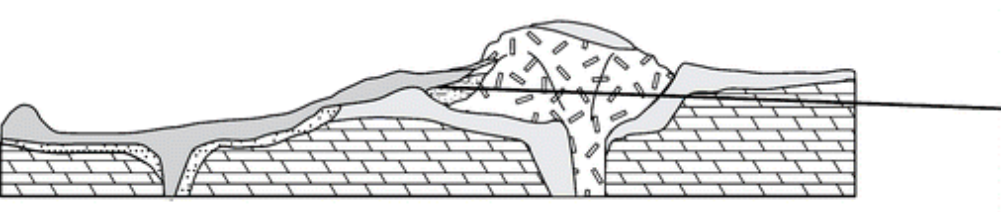

$\mathrm{pb}$ (south ring)

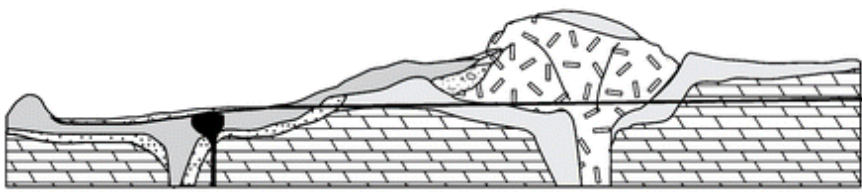

e
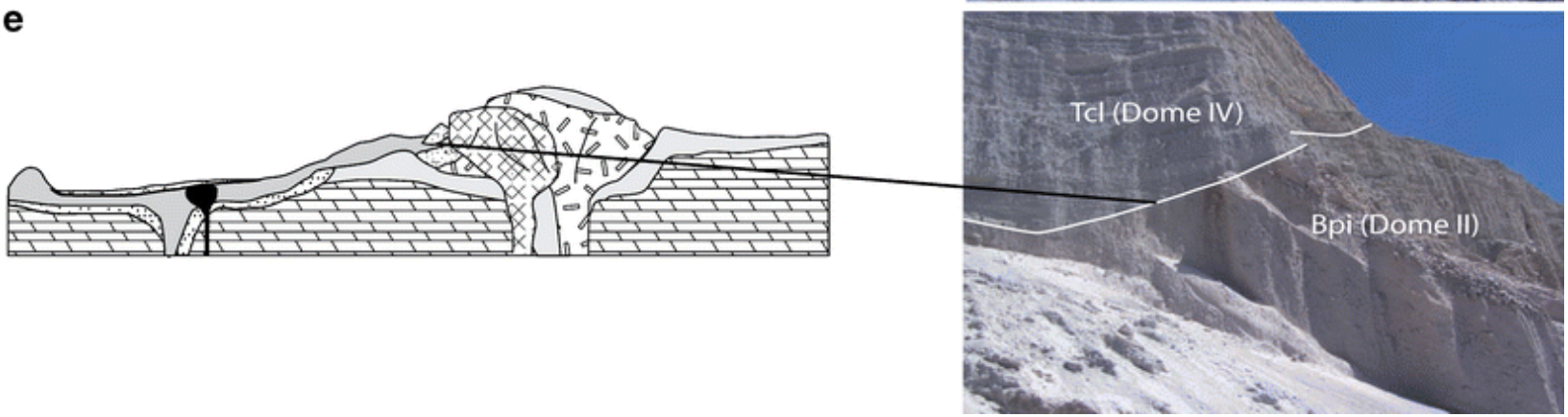

Fig. 9 Evolution diagram for Cerro Pinto. a. Stage I excavation of South ring; photo shows sub-facies Tpbx (cross-bedded biotite-rich pumice tephra). b. Stage I emplacement of Domes I and II. Tpb emplaced during building of the tuff ring uplifted on Dome II. Photo view to east. c. Stage II eruption of North tuff 
ring. Photo shows a scoured contact between facies Tcl (lithic-rich tephra) and Tpb of the South ring. $d$. Excavation of the northern and western inner rings. Deposits of all north ring eruptions are Tcl and Tp; deposits of different eruptions are distinguished by scoured contacts, as shown in photo. e. Stage III excavation of a small crater and emplacement of Dome IV. Photo shows Tcl within the crater cut into interbedded grain flow and surge deposits of facies association Bti

As the energy of the initial eruption diminished, Dome I and later Dome II were emplaced within the southern tuff ring. The mineralogy of facies Tpb and Dome I is identical (i.e., both contain abundant biotite, which other domes and deposits do not have), which suggests that the two are co-genetic. This progression from explosive to effusive phases in the south ring follows common models of dome emplacement in which a pyroclastic phase is immediately followed by an effusive phase (e.g., Duffield et al. 1995). The mineralogy of Dome II is similar to Dome I, but minerals differ in percentage and size (Table 1) and Dome II was not accompanied by any explosive eruption. The stratigraphic relation between the two domes is not exposed, but we infer that the two domes were emplaced separately, with Dome II being younger, and that both events preceded the eruption of the north ring.

Distorted beds (stretched, with uncertain bedding contacts) of Tpb on the sides of Dome II, together with subhorizontal beds at its summit lead us to infer that Dome II, and perhaps Dome I, were cryptodomal in part, and preserved crater-floor stratigraphy on the summit (Fig. 9b). Beds on the side of Dome II may represent deposits of surges that were "climbing" pre-existing topography, but we consider this less likely.

\section{Stage II-North Ring Activity}

With no significant hiatus in the eruption, explosive activity continued, excavating a second, surge-dominated tuff ring $\left(\sim 0.38 \mathrm{~km}^{3}\right)$ to the north of the south ring (Fig. 9c). Bomb sags and accretionary lapilli (Fig. 3c) in the basal, cross-bedded, lithic-rich deposits (Tcl) indicate that initial activity was phreatomagmatic with a minor fallout component. Cross bedding and scouring surfaces are common where Tcl deposits were emplaced over areas of steep topography, such as where the surges encountered tuff rings or domes. The cross-bedded, lithic-rich deposit is a maximum of $10 \mathrm{~m}$ thick though it is typically around $1 \mathrm{~m}$ thick, suggesting that the water source was quickly exhausted and the eruption continued as strictly magma driven, producing dominantly dry surge and fallout deposits of facies Tp ( $<125 \mathrm{~m}$ maximum thickness). More than $75 \%$ of the deposits were emplaced by fall. The north ring overlies an estimated 2-20 m of tephra from the original south ring eruption.

An undulating contact separates Tpb from overlying tephra of facies Tcl (Fig. 10b) and marks the contact between Stage I and Stage II tephra. Facies Tp then overlies facies Tcl marking the change from phreatomagmatic surge deposits to dominantly dry fallout deposits. The base of the sequence is not exposed, but the Tpb is inferred to overlie Cretaceous limestone based on this stratigraphic relation exposed to the southeast of the complex. Age relations between deposits in the north tuff ring are complex due to numerous eruptions within the ring. In distal areas of the complex, facies Tp tephra immediately overlie facies Tpb tephra (Fig. 10a). 


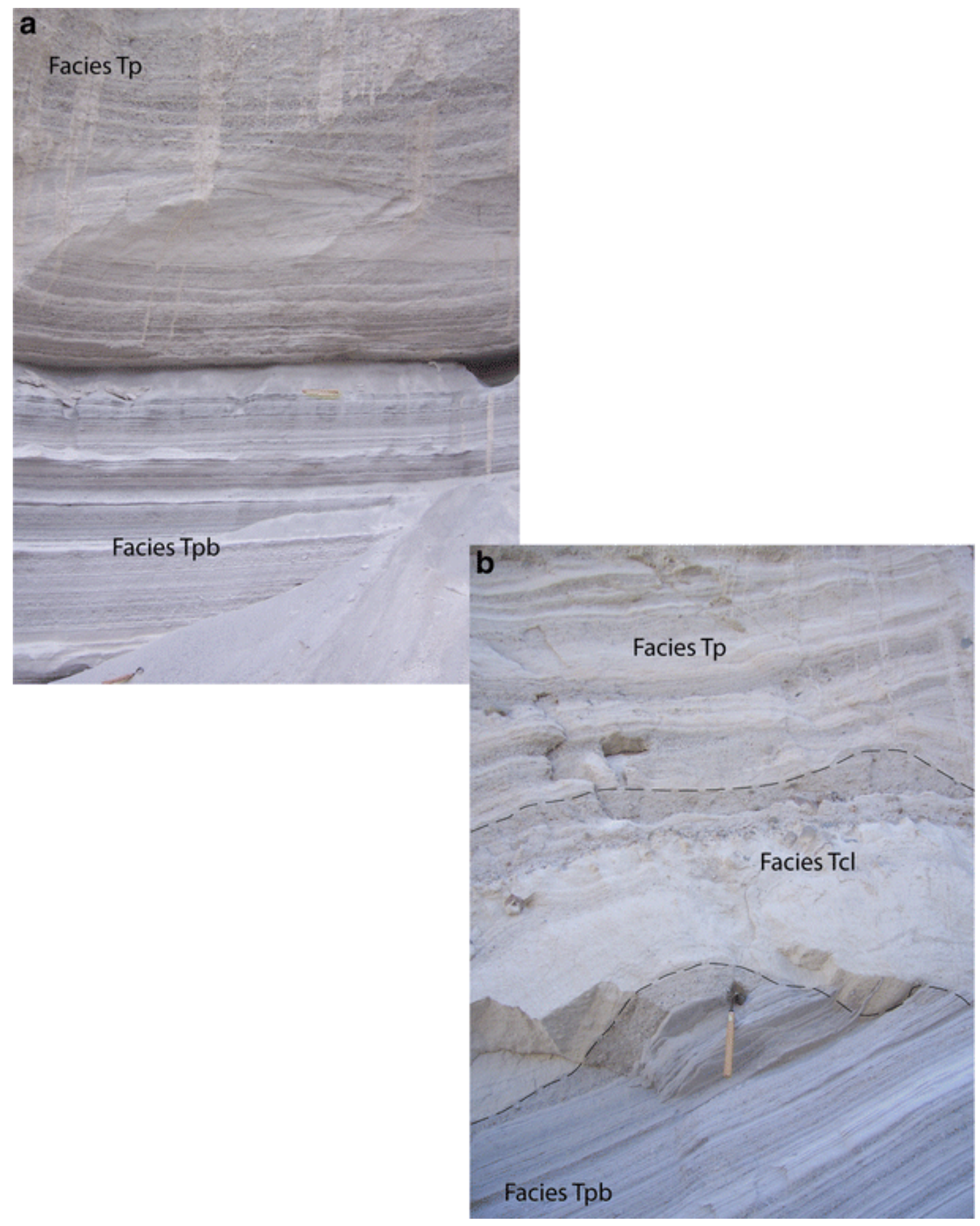

Fig. 10 Stratigraphic relations in the area of the quarry (see Fig. 2 for location). a, Tephra of facies Tpb overlain by facies Tp. The thin layer on which scale $(20 \mathrm{~cm})$ rests is inferred to represent water reworking of Tpb. b. Undulating contacts between tephra of facies Tcl and the underlying Tpb and overlying Tp facies tephra. Scraper handle is $\sim 30 \mathrm{~cm}$ 
Block-and-ash flow deposits (Bp) from Dome I are interbedded with surge and fall deposits from the north ring (Figs. 5 and 11; facies association Bti); we envision that during the north ring eruptions, the unstable, but semi-cooled dome partially collapsed on several occasions, yielding flows that do not have a significant juvenile pyroclastic component but rather reflect ash-rich, dry, mass flows that traveled as much as $200 \mathrm{~m}$ toward the north and filled in the topographic lows surrounding the domes in the south ring. A few flows crested the north rim of the south ring. The interbedded tephra deposits (facies association Bti) within the coarse beds were deposited as fallout and pyroclastic surges from explosive eruptions occurring to the north between block-andash flow events. The entire sequence is exposed within a quarry located at the junction of the north and south tuff rings (Figs. 2 and 11).
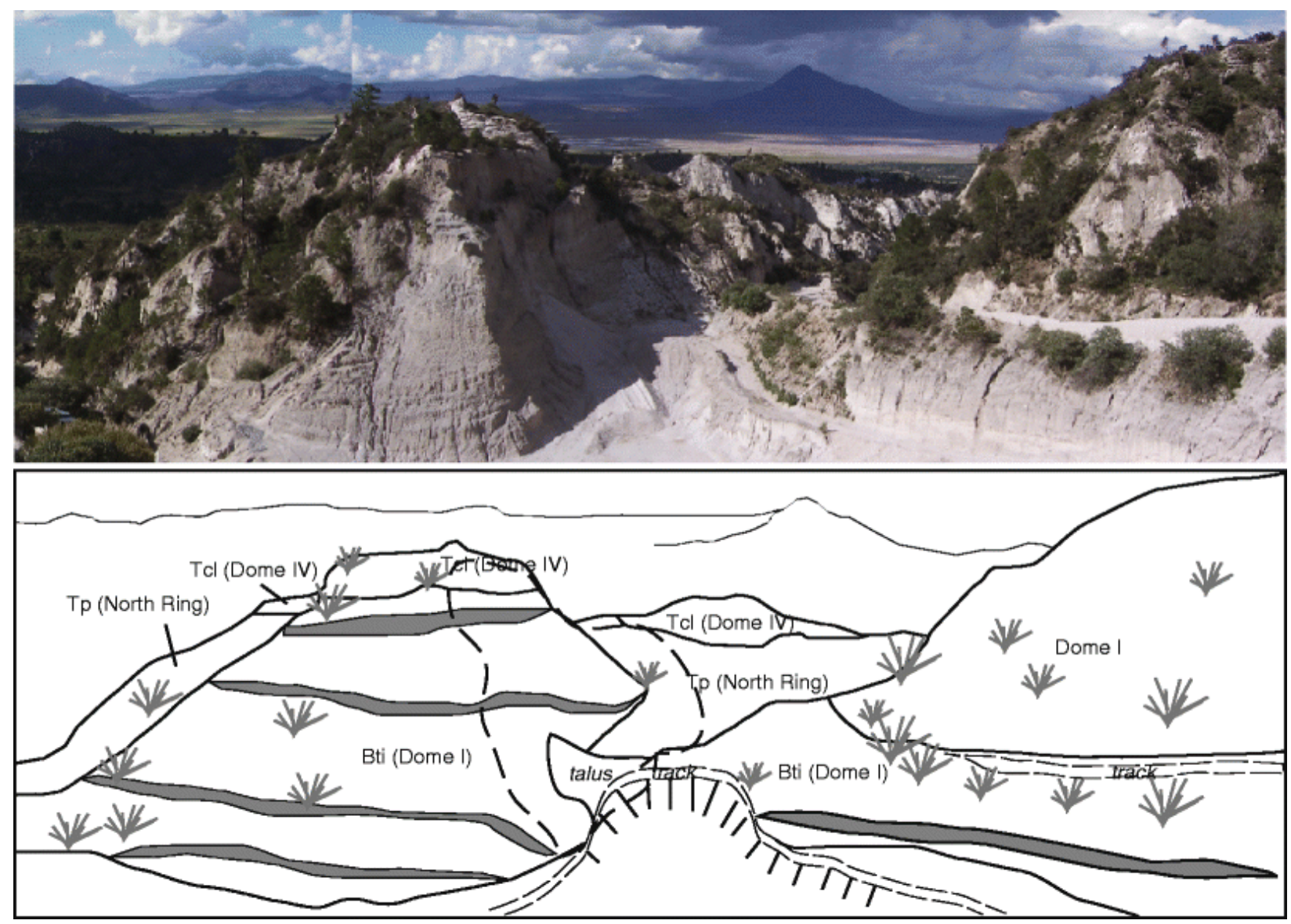

Fig. 11 Photo and sketch of the quarry area showing stratigraphic relations exposed. Facies and inferred source vent location for each deposit noted in lower sketch. Dark grey strips in the Bti deposits represent interbedded surge deposits described in text and Table 2 
Explosive activity in the north ring continued as vent migration initiated the growth of a third tuff ring nested within the northern tuff ring (Fig. 2a), referred to as the northern inner ring. Pumiceous fallout and surge deposits that form the northern inner ring are not as widely distributed as north ring tephra, but the northern inner ring deposits are generally thicker ( $<140 \mathrm{~m}$ maximum ring thickness), indicating that this eruption was less powerful, but more voluminous $\left(\sim 0.40 \mathrm{~km}^{3}\right)$ than deposits from the eruption that produced the northern ring. Truncating relations are the best evidence for deposits of different eruptions within the northern tuff ring (Fig. 9d). The basal deposits of the northern inner ring contain very few lithic clasts and rare biotite-phyric pumices (facies $\mathrm{Tpb}$ ), suggesting that the eruption was very shallow, perhaps mixing previously erupted biotite pumice with juvenile pumice tephra.

The western inner tuff ring $\left(\sim 0.015 \mathrm{~km}^{3}\right)$, an oblate ring elongated north/south (Fig. 2), was then emplaced within the northern tuff ring. This ring is dominated by pumiceous fallout deposits that were, in part, deformed by the intrusion of a small dome (Dome III). Bedding structures of the western inner ring are very difficult to distinguish and outcrops are small and localized. Maximum thickness of the ring is estimated to be $50 \mathrm{~m}$. The overall topography of the western inner ring is much more subdued than any of the other tuff rings at Cerro Pinto. Because of the lack of good exposures and the petrologic similarities of pumiceous tephra throughout the Cerro Pinto complex, the extent of the western inner ring tephra is not well constrained. However, the nesting of the northern rings suggests a gradual decrease in the overall energy of the eruption as time progressed with the western inner ring representing the final, least powerful tuff ring eruption of Stage II. Although we infer that the overall morphology of the north ring is due to at least three separate eruptions, the resulting deposits are all of facies $\mathrm{Tp}$, and unconformities between sections of Tp are inferred to be between deposits of different eruptions (Fig. 9d).

Following the tuff ring eruptions, Stage II continued with the effusive emplacement of a small dome (Dome III) within the western inner ring. The dome occurs as only one 2meter-high exposure that comprises hydrothermally altered and friable lava, suggesting that hydrothermal fluids circulated from the dome. Dome III may have primarily been a cryptodome that did not emerge from beneath the uplifted tephra blanket during its emplacement.

The final event of Stage II was the explosive destruction of a dome by blasts directed to the north that produced the monolithic-breccia-and-ash deposit (Mba; Figs. 2 and 6) that covers much of the northern tuff ring and extends up to $1 \mathrm{~km}$ northeast of the north ring's rim. The monolithic-breccia-and-ash deposit is interpreted to be an explosion breccia emplaced by a combination of depositional processes including ballistic emplacement, represented by outsize blocks in all three members and bomb sags in the upper member, pyroclastic flow as suggested by the coarse but poorly sorted basal 
member, fallout represented by the lapilli-size lava-clast support in the middle member, and surge processes that are indicated by the presence of cross-bedded sections in the upper bed. The eruption of Mba may record destruction of Dome III; this interpretation is based on the spatial relation of the deposit to Dome III and the alteration and very small relict size of that dome.

\section{Stage III-Final Dome Emplacement}

During the final eruptive stage, activity migrated back to the southern tuff ring where vent clearing produced an ejecta ring within volcaniclastic deposits at the northern edge of the southern tuff ring (Fig. 9e). Moderate amounts of surge and fallout tephra are correlated with this pyroclastic phase, but the deposits are small and localized around Dome IV, mantling the topography and forming no coherent ring of their own. These deposits cap the quarry section with $\sim 2 \mathrm{~m}$ of facies Tcl with tabular foresets, antidunes, and bombsags; orientations indicate derivation from the south tuff ring.

Dome IV grew endogenously within the crater and produced one small block-and-ash flow deposit $\left(\sim 30,000 \mathrm{~m}^{3}\right)$ to the northeast. The Dome IV eruption also included a pyroclastic flow $\left(\sim 25,000 \mathrm{~m}^{3}\right)$ that filled a paleodrainage to the north of the crater and fanned out into the north ring. This pyroclastic flow (Tma) is exposed in one major lobe channeled into facies Tp adjacent to the quarry road (Fig. 4). The concentration of pumice blocks in the upper portion of the deposit is consistent with rafting of blocks during transport. The orientation of the channel strongly suggests that the flow originated from the south ring and the stratigraphic position indicates it was a product of a late-stage eruption.

Surge and fall deposits of facies Tpb and Tp are exposed atop Dome II and Dome IV. Dome IV has $<1 \mathrm{~m}$ of tephra overlying it comprising both facies Tp and Tpb. It is likely that Dome I was also initially blanketed by tephra. However, its more rounded morphology and subsequent weathering patterns have left no appreciable tephra deposits intact on the summit. ${ }^{40} \mathrm{Ar} /{ }^{39} \mathrm{Ar}$ dating of sanidine crystals from coherent Dome IV lava returned a date of $62 \pm 8 \mathrm{ka}$ (Table 4), marking the end of eruptive activity at Cerro Pinto. 
Table $4{ }^{40} \mathrm{Ar} /{ }^{39} \mathrm{Ar}$ isotopic age of Cerro Pinto dome lava ${ }^{\mathrm{a}}$

\begin{tabular}{|c|c|c|c|c|c|c|c|c|c|c|}
\hline ID & $\begin{array}{l}\text { Power } \\
\text { (watts } \\
\text { ) }\end{array}$ & ${ }_{r}^{40} \mathrm{Ar} /{ }^{39} \mathrm{~A}$ & ${ }^{37} \mathrm{Ar} /{ }^{39} \mathrm{Ar}$ & $\begin{array}{l}{ }^{36} \mathrm{Ar} /{ }^{39} \mathrm{~A} \\
\mathrm{r}(\mathrm{x} \\
\left.10^{-3}\right)\end{array}$ & $\begin{array}{l}{ }^{39} \mathrm{ArK} \\
\left(\mathrm{x10}{ }^{-1}\right. \\
\left.{ }^{5} \mathrm{~mol}\right)\end{array}$ & K/Ca & $\begin{array}{l}{ }^{40} \mathrm{Ar} \\
(\%)\end{array}$ & $\begin{array}{l}{ }^{39} \mathrm{Ar} \\
(\%)\end{array}$ & $\begin{array}{l}\text { Age } \\
\text { (Ma) }\end{array}$ & $\begin{array}{l} \pm \mathbf{1 \sigma} \\
\text { (Ma) }\end{array}$ \\
\hline A & 3 & 7.281 & 0.1969 & 23.01 & 7.03 & 2.6 & 6.4 & 6.8 & $\begin{array}{l}0.11 \\
4\end{array}$ & $\begin{array}{l}0.01 \\
4\end{array}$ \\
\hline B & 5 & 0.3571 & 0.1052 & 0.3470 & 52.6 & 4.9 & 71.3 & 58.0 & $\begin{array}{l}0.05 \\
7\end{array}$ & $\begin{array}{l}0.00 \\
1\end{array}$ \\
\hline C & 6 & 0.3236 & 0.0797 & 0.0428 & 20.1 & 6.4 & 97.9 & 77.6 & $\begin{array}{l}0.07 \\
0\end{array}$ & $\begin{array}{l}0.00 \\
2\end{array}$ \\
\hline D & 7 & 0.5163 & 0.0768 & 0.4407 & 8.13 & 6.6 & 74.5 & 85.5 & $\begin{array}{l}0.08 \\
8\end{array}$ & $\begin{array}{l}0.00 \\
5\end{array}$ \\
\hline E & 8 & 0.4299 & 0.0693 & 0.0046 & 3.99 & 7.3 & $\begin{array}{l}101 . \\
1\end{array}$ & 89.4 & \begin{tabular}{|l|}
0.09 \\
8
\end{tabular} & $\begin{array}{l}0.00 \\
9\end{array}$ \\
\hline F & 10 & 0.5128 & 0.1054 & 0.0380 & 2.79 & 4.8 & 99.5 & 92.1 & $\begin{array}{l}0.11 \\
7\end{array}$ & $\begin{array}{l}0.01 \\
5\end{array}$ \\
\hline G & 12 & 0.5557 & 0.1187 & 0.7309 & 2.43 & 4.3 & 60.8 & 94.4 & $\begin{array}{l}0.07 \\
8\end{array}$ & $\begin{array}{l}0.01 \\
0\end{array}$ \\
\hline $\mathrm{H}$ & 16 & 1.022 & 0.1135 & 1.831 & 1.49 & 4.5 & 46.4 & 95.9 & $\begin{array}{l}0.11 \\
2\end{array}$ & $\begin{array}{l}0.01 \\
7\end{array}$ \\
\hline I & 20 & 1.431 & 0.1158 & 3.369 & 1.56 & 4.4 & 29.6 & 97.4 & $\begin{array}{l}0.10 \\
1\end{array}$ & $\begin{array}{l}0.02 \\
0\end{array}$ \\
\hline $\mathrm{J}$ & 25 & 3.906 & 0.1017 & 10.43 & 1.48 & 5.0 & 20.7 & 98.9 & $\begin{array}{l}0.19 \\
5\end{array}$ & $\begin{array}{l}0.02 \\
4\end{array}$ \\
\hline K & 30 & 11.61 & 0.0998 & 35.33 & 1.18 & 5.1 & 9.9 & $\begin{array}{l}100 . \\
0\end{array}$ & $\begin{array}{l}0.27 \\
8\end{array}$ & $\begin{array}{l}0.04 \\
4\end{array}$ \\
\hline $\begin{array}{l}\text { Integrated } \\
\text { age } \pm 2 \sigma\end{array}$ & $n=11$ & & & 102.7 & & $\begin{array}{l}5.1 \pm 2 . \\
6\end{array}$ & & & $\begin{array}{l}0.07 \\
5 \\
\end{array}$ & $\begin{array}{l}0.00 \\
3\end{array}$ \\
\hline $\begin{array}{l}\text { Plateau } \pm 2 \\
\sigma\end{array}$ & $n=11$ & & $\begin{array}{l}\text { MSWD }=18 \\
6\end{array}$ & 102.7 & & $\begin{array}{l}5.1 \pm 2 . \\
6\end{array}$ & & & $\begin{array}{l}0.06 \\
2\end{array}$ & $\begin{array}{l}0.00 \\
8\end{array}$ \\
\hline
\end{tabular}

${ }^{2}{ }^{40} \mathrm{Ar} /{ }^{39} \mathrm{Ar}$ dating performed at New Mexico Geochronology Lab using a MAP215-50 mass spectrometer on sample PIN02-6 sanidine; see Table $\underline{1}$ for sample description. Location of sample $2143000 \mathrm{~N}$ 0658078E Integrated age is volume-weighted mean of all steps Plateau age error in inverse-variance-weighted mean error (Taylor, 1982) x root MSWD where MSWD > 1

Decay constants and isotopic abundances after Steiger and Jäger (1977) $\mathrm{J}=0.0001347 \pm 0.26 \%$

Ages calculated relative to FC-2 Fish Canyon Tuff sanidine interlaboratory standard at $28.02 \mathrm{Ma}$

Decay Constant $($ LambdaK (total) $)=5.543 \mathrm{e}^{-10}$

Discrimination $=1.0063 \pm 0.001$ 
Correction factors:

$\left({ }^{39} \mathrm{Ar} /{ }^{37} \mathrm{Ar}\right)_{\mathrm{c}} \mathrm{a}=0.00075 \pm 5 \mathrm{e}^{-0.5}$

$\left({ }^{36} \mathrm{Ar} /{ }^{37} \mathrm{Ar}\right)_{\mathrm{c}} \mathrm{a}=0.00028 \pm 5 \mathrm{e}^{-0.5}$

$\left({ }^{38} \mathrm{Ar} /{ }^{39} \mathrm{Ar}\right)_{\mathrm{K}}=0.0125$

$\left({ }^{40} \mathrm{Ar} /{ }^{39} \mathrm{Ar}\right)_{\mathrm{K}}=0.03 \pm 0.002$

\section{Discussion}

While some rhyolite domes follow a simple, unidirectional eruptive sequence, this study, together with those of Riggs and Carrasco-Núñez (2004) and Carrasco-Núñez and Riggs (2008), suggest that isolated domes have the capacity to produce significantly more complex emplacement sequences. The arresting feature of Cerro Pinto that separates it from other documented cases of rhyolitic dome growth is that Cerro Pinto is a fallout-dominated tuff ring-dome complex that oscillated multiple times between explosive and effusive behavior over a relatively short time interval while most likely sourced by a single, small, chemically distinctive, magma chamber.

The migration of the eruptive activity back and forth along a relatively restricted corridor is potentially related to structural trends within the basin. Faults are aligned N-S, like Cerro Pinto's vents, and have been correlated with many young volcanic edifices in the Pico de Orizaba-Cofre de Perote range (Campos-Enriquez and Garduno Monroy 1987). In the case of Cerro Pinto, it is possible that a small-volume dike used a fracture along the N-S lineament as a conduit to the surface. The textural and mineralogical variability of the different dome lavas could be attributed to the magmas being drawn from a density stratified dike similar to the process proposed for the Inyo volcanic chain (Blake and Fink 1987; Reches and Fink 1988). The dome lava at Cerro Pinto had minimal evidence of magma mixing from any single vent, suggesting relatively small draw up depths if the source was, in fact, a small-volume dike. While dikes are proposed to have scattered and periodic exsolution of volatiles due to tectonic stresses (Reches and Fink 1988), we believe phreatomagmatism triggered each eruption due to the strong correlation between the Tcl deposits and new eruptive stages. A hybrid interpretation would include a shallow dike that encountered intermittent meteoric water, groundwater, or saturated sediments as it migrated through the upper crust, triggering phreatomagmatic eruptions.

\section{Phreatomagmatism}

In a recent experiment, Austin-Erickson et al. (2008) determined that high-silica melts differ from lower-viscosity melts in how they interact with water during phreatomagmatic explosions produced under laboratory conditions. The authors concluded that under natural conditions, stress-induced magma fracturing may lead to critical magma-waterinterface growths, initiating phreatomagmatic explosions and brittle-type fragmentation of high-silica magmas. These results agree with the field evidence seen at Tepexitl tuff ring (Austin-Erickson et al. 2008) and support our interpretations for Cerro Pinto. 
Nearly every stage of eruptive activity at Cerro Pinto began with a wet, lithic-rich, surgedominated phase, but quickly changed to a dry, fallout-dominated environment. The thickest wet-surge deposits are only $10 \mathrm{~m}$ thick, whereas the dry, pumiceous tephra is commonly over $50 \mathrm{~m}$ thick. The relatively small volume of wet-surge material and the lack of any cementation or ubiquitous hydrothermal alteration suggests that the water in this interaction was either groundwater or saturated pre-existing tephra; a lake would have held enough water to make a substantially larger volume of phreatomagmatic deposits and would also have significantly influenced the sorting, distribution, and subsequent alteration of the pyroclastic tephra (cf. Fisher and Schmincke 1984; Brooker et al. 1993). Phreatomagmatic eruptions also often lead to highly heterogeneous erupted material including high concentrations of lithic clasts and hydrothermally altered clasts (White and Houghton 2000). Such clasts are found only in the $<10$ m-thick crossbedded lithic-rich tephra (facies Tcl) at Cerro Pinto. Both Tepexitl and Cerro Pinto had small domes destroyed by retrogressive phreatomagmatic explosions (Austin-Erickson et al. 2008; this study). In both cases, there is little evidence of the original dome morphology above the crater floors. Instead, the existence of the domes is inferred by the coarse breccia deposits the explosions produced.

\section{Fall-Dominated Tuff Rings}

As a fallout-dominated tuff ring-dome complex, Cerro Pinto has few reported analogs. Brooker et al. (1993) discussed the Puketarata tuff ring (New Zealand) and documented a succession of fall deposits that are common throughout the ring, though dominant only in distal deposits. Several characteristics differentiate Cerro Pinto from Puketarata. Most significant is the dominance of fall deposits in proximal parts of Cerro Pinto: at all stages fall was the dominant mechanism of deposition. Fall deposits at Cerro Pinto are dominantly vesicular pumice, whereas those at Puketarata are blocky and poorly vesicular. Similar to Cerro Pinto, Brooker et al. (1993) documented a relative paucity of wall-rock lithic fragments in the fall deposits.

Brooker et al. (1993) inferred that largely degassed magma encountered external water at Puketarata, and that explosions occurred at very shallow depths. They inferred that overall, in the absence of abundant water in the early phases of the eruption and ponded rainwater in the later phases, dome growth would have dominated the eruptive history. This contrasts with Cerro Pinto, where we have documented sustained pyroclastic activity, much of which was dry and likely sub-Plinian, followed by extrusion of a dome. Water was available at times, especially in the initial phases of each eruptive stage, but no evidence exists to suggest a significant source. We infer that each eruptive stage began with vesiculating magma encountering groundwater, though likely not in large amounts, as suggested by the relatively coarse size of pumice fragments $(0.2-3 \mathrm{~cm})$ in the surge deposits. This relatively minor water was exhausted, but fragmentation continued, yielding tuff-ring-wall thicknesses of as much as $150 \mathrm{~m}$. 


\section{Conclusions}

The evolution of Cerro Pinto included three distinct stages of development. Stage I began with the formation of the southern tuff ring and the growth of domes I and II. During Stage II, activity moved north, creating the northern tuff ring, the northern inner ring, the western inner ring and Dome III. Dome III is believed to have been mostly destroyed in blasts directed to the north that deposited the monolithic-ash-breccia that caps the north ring stratigraphic sequence. In the final stage, Stage III, emplacement of Dome IV along the northern margin of the southern tuff ring followed explosive excavation of a crater.

Dome growth throughout the eruptive sequence at Cerro Pinto was, in part, similar to current simple dome models, but also diverged significantly in other aspects, specifically the oscillations between explosive and effusive activity, the production of multiple tuff rings dominated by fall deposits, vent migration, and partial to complete dome collapses. Vent migration may have occurred along a N-S lineament consistent with regional structural trends when the main vent was plugged by a cooling lava dome. Each new stage of the emplacement sequence began with a highly explosive, ventclearing eruption, sometimes producing large volumes of tephra. The emplacement sequence was complicated by phreatomagmatic interactions with ground water. The source was likely a small-volume chamber or dike that was isolated from the magma sources of surrounding volcanic structures. No field evidence exists to suggest a significant hiatus of activity at any point during the eruptive sequence and it can therefore be inferred that the entire emplacement of the dome complex could not have taken more than a few months to years. The homogeneous chemistry exhibited by the pyroclast and lava samples of Cerro Pinto also favor this hypothesis.

Cerro Pinto's behavior was likely the result of the influence of water combined with normal volcanic processes. Because of this, the eruptive variations described here should be considered distinct possibilities when assessing hazards of newly emerging rhyolite domes, whether they are emplaced in fields, in isolation, or near calderas and stratovolcanoes.

Acknowledgements This manuscript benefited greatly from reviews by J Fink, G Sottili, and $\mathrm{H}$ Delgado Granados. Additional comments were graciously provided by W Duffield. M Ketterer performed ICP-MS analyses, R Lozano ran the XRF, and L Peters (New Mexico Bureau of Mines and Mineral Resources) provided the ${ }^{40} \mathrm{Ar} /{ }^{39} \mathrm{Ar}$ dates. Financial assistance and XRF analyses were generously provided by Universidad Nacional Autónoma de México (UNAM); PAPIIT IN107907 and the Friday Lunch Clubbe of Northern Arizona University. We would also like to thank C Melendez, M Branney, G Aguirre, F Cedillo, M Ort, C Bonamici, and A Austin for fruitful discussions in the field. 


\section{References}

Abrams MJ, Siebe C (1994) Cerro Xalapaxco: an unusual tuff cone with multiple explosion craters, in central Mexico (Puebla). J Volcanol Geotherm Res 63:183-199

Austin-Erickson A (2007) Phreatomagmatic eruptions of rhyolitic magma: A case study of Tepexitl tuff ring, Serdan-Oriental basin, Mexico. MS thesis, Northern Arizona University, Flagstaff

Austin-Erickson A, Büttner R, Dellino P, Ort MH, Zimanowski B (2008) Phreatomagmatic explosions of rhyolite magma: experimental and field evidence. J Geophys Res 113:B11201. doi:10.1029/2008JB005731

Blake S, Fink JH (1987) The dynamics of magma withdrawal from a density stratified dyke. Earth Planet Sci Lett 85:516-524

Brooker MR, Houghton BF, Wilson CJN, Gamble JA (1993) Pyroclastic phases of a rhyolitic dome-building eruption: Puketarata tuff ring, Taupo Volcanic Zone, New Zealand. Bull Volcanol 55:395-406

Campos-Enriquez JO, Garduno Monroy VH (1987) The shallow structure of Los Humeros and Las Derrumbadas geothermal fields, Mexico. Geothermics 16:539-554

Carrasco-Núñez G, Ort M, Romero C (2007) Evolution and hydrological conditions of a maar volcano (Atexcac crater, Eastern Mexico). J Volcanol Geotherm Res 159:179-197

Carrasco-Núñez G, Riggs NR (2008) Polygenetic nature of a rhyolitic dome and implications for hazard assessment: Cerro Pizarro volcano, Mexico. J Volcanol Geotherm Res 171:307-315

Chough SK, Sohn YK (1990) Depositional mechanics and sequences of base surges, Songaksan tuff ring, Cheju Island, Korea. Sedimentology 37:1115-1135 
Duffield WA, Richter DH, Priest SS (1995) Physical volcanology of silicic lava domes as exemplified by the Taylor Creek Rhyolite, Catron and Sierra Counties, New Mexico. US Geol Surv Map I-2399, scale 1:50,000

Ferriz H, Mahood G (1984) Eruprion rates and compositional trends at Los Humeros volcanic center, Puebla, Mexico. J Geophys Res 89:8511-8524.

doi:10.1029/JB089iB10p08511

Fisher RV, Schmincke H-U (1984) Pyroclastic rocks. Springer-Verlag, Berlin

Garcia-Banda R (1984) Geology, geochemistry, and petrology of the Pizarro and Pinto domes and the Tepeyahualco flows related to the Los Humeros caldera complex, Puebla, Mexico. MSc thesis, McGill University, Montreal

Heiken GH, Wohletz K (1987) Tephra deposits associated with silicic domes and lava flows. Geol Soc Am Spec Pap 212:55-76

Hildreth W (2004) Volcanological perspectives on Long Valley, Mammoth Mountain, and Mono Craters: several contiguous but discrete systems. J Volcanol Geotherm Res 136:169-198

Hildreth W, Fierstein J (2000) Katmai volcanic cluster and the great eruption of 1912. Geol Soc Am Bull 112:1594-1620

Houghton BF, Wilson CJN, Fierstein J, Hildreth W (2004) Complex proximal deposition during the Plinian eruptions of 1912 at Novarupta, Alaska. Bull Volcanol 66:95-133

Lozano-Santa Cruz R, Verma SP, Girón P, Velasco F, Morán D, Viera F, Chávez G (1995) Calibración preliminar de fluorescencia de rayos-X para análisis cuantitativo de elementos mayores en rocas ígneas. Acta INAGEQ 1:203-208

Macias JL, Sheridan MF (1995) Products of the 1907 eruption of Shtyubel' Volcano, Ksudach Caldera, Kamchatka, Russia. Geol Soc Am Bull 107:969-985 
Miller CD (1985) Holocene eruptions at the Inyo volcanic chain, California: implications for possible eruptions in the Long Valley caldera. Geology 13:14-17

Ort M, Carrasco-Núñez G (2009) Lateral vent migration during phreatomagmatic and magmatic eruptions at Tecuitlapa maar, east-central Mexico. J Volcanol Geotherm Res 181:67-77

Reches Z, Fink JH (1988) The mechanism of intrusion of the Inyo dike, Long Valley Caldera, California. J Geophys Res 93:4321-4334. doi:10.1029/JB093iB05p04321

Riggs NR, Carrasco-Núñez G (2004) Evolution of a complex, isolated dome system, Cerro Pizarro, central México. Bull Volcanol 66:322-335

Sampson DE, Cameron KL (1987) The geochemistry of the Inyo volcanic chain: multiple magma systems in the Long Valley region, eastern California. J Geophys Res 92:10403-10421. doi:10.1029/JB092iB10p10403

Sheridan MF, Updike RG (1975) Sugarloaf Mountain Tephra—A Pleistocene rhyolitic deposit of base-surge origin in northern Arizona. Geol Soc Am Bull 86:571-581

Siebe C, Verma SP (1988) Major element geochemistry and tectonic setting of Las Derrumbadas rhyolitic domes, Puebla, Mexico. Chem Erde 48:177-189

Siebe C, Macías JL, Abrams M, Rodríguez S, Castro R, Delgado H (1995) Quaternary explosive volcanism and pyroclastic deposits in east central Mexico: implications for future hazards. Geol Soc Am Field Guide, pp 1-47

Siebert L, Carrasco-Nuñez G (2002) Late-Pleistocene to precolumbian behind-the-arc mafic volcanism in the eastern Mexican Volcanic Belt; implications for future hazards. J Volcanol Geotherm Res 115:179-205 
Steiger RH, Jäger E (1977) Subcommission on geochronology: convention on the use of decay constants in geo- and cosmochronology. Earth Planet Sci Lett 36:359-362

Sun S, McDonough WF, (1989) Chemical and isotopic systematics of ocean basalt: Implications for mantle composition and processes. In: Saunders AD, Norry MJ (eds) Magmatism in ocean basins. Geol Soc London Spec Pub 42:313-345

Swanson SE, Naney MT, Westrich HR, Eichelberger JC (1989) Crystallization history of Obsidian Dome, Inyo Domes, California. Bull Volcanol 51:161-176

Taylor JR (1982) An introduction to error analysis: The study of uncertainties in physical measurements. Univ Sci Books, Mill Valley

White JDL, Houghton BF (2000) Surtseyan and related phreatomagmatic eruptions. In: Sigurdsson H, Houghton B, McNutt S, Rymer H, Stix J (eds) Encyclopedia of volcanoes. Academic, San Diego, pp 617-626

Yañez C, García S (1982) Exploración geotérmica de la region geotérmica Los Humeros-Las Derrumbadas, estados de Puebla y Veracruz. C.F.E. 96 